\title{
Biostimulants Managed Fungal Phytopathogens and Enhanced Activity of Beneficial Microorganisms in Rhizosphere of Scorzonera (Scorzonera hispanica L.)
}

\author{
Elżbieta Patkowska (iD
}

check for

updates

Citation: Patkowska, E.

Biostimulants Managed Fungal

Phytopathogens and Enhanced

Activity of Beneficial Microorganisms

in Rhizosphere of Scorzonera

(Scorzonera hispanica L.). Agriculture

2021, 11, 347. https://doi.org/

10.3390/agriculture11040347

Academic Editors: Catello Pane and Gelsomina Manganiello

Received: 14 March 2021

Accepted: 10 April 2021

Published: 13 April 2021

Publisher's Note: MDPI stays neutral with regard to jurisdictional claims in published maps and institutional affiliations.

Copyright: (C) 2021 by the author Licensee MDPI, Basel, Switzerland. This article is an open access article distributed under the terms and conditions of the Creative Commons Attribution (CC BY) license (https:/ / creativecommons.org/licenses/by/ $4.0 /)$.
Department of Plant Protection, Faculty of Horticulture and Landscape Architecture, University of Life Sciences in Lublin, 20-069 Lublin, Poland; elzbieta.patkowska@up.lublin.pl; Tel.: +48-815-248-109

\begin{abstract}
The principles of good agricultural and horticultural practice, considering both environmental protection and high yielding of plants, require modern cultivation methods. In modern agriculture, it is possible to use biostimulants that protect the soil against degradation and plants against phytopathogens and stress. The purpose of 3-year field and laboratory studies was to determine the effect of Trichoderma harzianum T-22 and other biostimulants on the health status of scorzonera (Scorzonera hispanica L.) plants and microorganism populations in the rhizosphere of this plant. For this purpose, Biosept Active (a.s.-grapefruit extract), Timorex Gold 24 EC (based on tea tree oil), Trianum P (spores of Trichoderma harzianum Rifai T-22) and Zaprawa Nasienna T 75 DS/WS fungicide (a.s.- tiuram) were applied for the pre-sowing seed dressing of scorzonera cv. "Duplex". The number of seedlings and the health status of scorzonera plants were determined during three growing seasons. In each year of the study, mycological analysis of seedling roots and roots after scorzonera harvest was conducted to establish the quantitative and qualitative composition of fungi colonizing these parts. Moreover, microbiological analyses of scorzonera rhzisphere soil were conducted and served as the basis to determine the total population of fungi and bacteria (including Pseudomonas sp. and Bacillus sp.). Antagonistic activity of rhizosphere bacteria Pseudomonas sp., Bacillus sp. and fungi was determined based on laboratory tests on selected scorzonera soil-borne fungal pathogens (Alternaria scorzonerae, Fusarium culmorum, Fusarium oxysporum, and Rhizoctonia solani). The experiments showed that Trianum P most effectively protected the roots of scorzonera against infection by Alternaria alternata, A. scorzonerae, Neocosmospora solani, Fusarium spp., Sclerotinia sclerotiorum, Rhizoctonia solani, and Botrytis cinerea. The rhizosphere population of Bacillus sp. and Pseudomonas sp. in the treatments with Trianum P or Zaprawa Nasienna T 75 DS/WS was larger than in the other experimental treatments. A reverse relationship was observed in the population of rhizosphere fungi. The application of grapefruit extract, tea tree oil and Trichoderma harzianum T-22 increased antagonistic activity of Pseudomonas sp., Bacillus sp. and selected saprotrophic fungi against soil-borne fungal pathogens, especially Alternaria sp., Rhizoctonia sp., and Fusarium sp. In summary, Biosept Active, Timorex Gold 24 EC and Trianum P can be recommended as plant biostimulants in Scorzonera hispanica cultivation.
\end{abstract}

Keywords: scorzonera; organic farming; biostimulants; beneficial soil microorganisms; antagonistic bacteria and fungi

\section{Introduction}

High human awareness of the need to lead a hygienic lifestyle, including healthy eating, and the necessity to protect the environment, require modern agriculture and horticulture to apply sustainable farming and plant cultivation methods. Too intensive cultivation practices reduce soil fertility and its biodiversity [1-3]. They lead to the accumulation of harmful microorganisms, including phytopathogens and pesticides and their derivatives in soils and plants [4,5]. Suitable conditions for the growth and development 
of plants can be achieved by maintaining high activity and biodiversity of beneficial soil microorganisms, by more complex agricultural management, and by applying biological plant protection [6-9]. In modern agriculture, it is possible to use biostimulants that protect the soil against degradation and plants against phytopathogens and stress.

Scorzonera (Scorzonera hispanica L.), is a little known root vegetable that belongs to the family Asteraceae, and it is rarely cultivated worldwide [10,11]. Wild-growing forms of scorzonera occur in Southern Germany and France, Spain, and the Caucasus [10]. These include the following species: Scorzonera humilis L., Scorzonera purpurea L. and Scorzonera rosea W.K. In Turkey, Scorzonera sandrasica Hartvig and Strid, Scorzonera pisidica Hub.-Mor., Scorzonera gokcheoglui Ünal and Göktürk and Scorzonera longiana Sümbül can be encountered [12]. The cultivated species Scorzonera hispanica L. deserves to be disseminated among consumers and producers due to its high biological value [10,12]. It can successfully enrich the assortment of fresh vegetables in the early spring and winter [10]. In addition to the extremely valuable inulin, the roots of scorzonera contain carbohydrates, glycosides (choline, asparagine, lactucine and coniferin), polyphenolic acids, vitamins (vitamin C, riboflavin, thiamine and niacin), and minerals (magnesium, calcium, iron, phosphorus, potassium, and sodium) $[10,11,13]$. Scorzonera and its products are effective in the prevention and treatment of cardiovascular, gastrointestinal, kidney, diabetes, and even cancer diseases $[11,14]$.

These numerous health-promoting and healing properties of scorzonera should encourage farmers to cultivate this plant species. This is associated with the necessity to obtain a large and good-quality root yield $[10,15]$. The health-promoting properties of root vegetables, including scorzonera, is determined, among others, by physical and biochemical properties of the arable environment $[10,16]$ and biodiversity of soil microorganisms, especially the presence of soil-borne pathogens $[6,17,18]$. Despite the relatively rare cultivation of scorzonera, information about infectious agents that threaten this species is available in the literature. According to Loerakker [19], alternariosis of Scorzonera hispanica is caused by Alternaria scorzonerae. Downy mildews of the genera Plasmopara and Bremia may occur on the above-ground plant organs [20]. Soil-borne fungi such as Alternaria alternata, Fusarium oxysporum, F. culmorum, Neocosmospora solani, and Rhizoctonia solani infect seedling roots as well as the roots of older scorzonera plants [21,22]. Proper soil microbiological activity promotes the growth and development of scorzonera, at the same time protecting its roots from contamination by soil-borne pathogens. Therefore, appropriate methods of growing Scorzonera hispanica should be used, which would limit its infestation by phytopathogens. Such conditions can be obtained by using biostimulants, PGPMs (plant growth-promoting microorganisms) and PGRs (plant growth regulators) in plant cultivation $[6,23,24]$. They protect the soil from degradation and plants from phytopathogens and stress [23,25].

According to Ricci et al. [26], a plant biostimulant is: "A product stimulating plant nutrition processes independently of the product's nutrient content, with the aim of improving one or more of the following characteristics of the plant: Nutrient use efficiency, tolerance to abiotic stress, crop quality traits or availability of confined nutrients in the soil and rhizosphere". Moreover, high effectiveness of biostimulants (especially those based on Trichoderma) was demonstrated by many authors in plant protection against pathogens $[27,28]$. Biostimulants increasing the tolerance of plants to abiotic and biotic stress [27-29] also include microorganisms that induce plant resistance to pathogens and modify the composition of soil microorganisms and microorganisms colonizing underground plant organs $[25,28,30]$. The use of natural preparations is particularly important due to the need to minimize the harmful effects of chemization and to preserve the biodiversity of agroecosystems.

The main active substances used in such preparations are beneficial fungal and bacterial agents, protein hydrolysates, fulvic and humic acids, salicylic acid, seaweed extracts, and compounds containing nitrogen [20-32]. Useful microorganisms applied as biostimulants include, among others, bacteria: Pseudomonas spp., Bacillus spp., Arthrobacter spp., Enterobacter spp., Rhodococcus spp., Ochrobactrum spp., Serratia spp. [23,33-35] 
and fungi: Trichoderma harzianum, Trichoderma reesei, Trichoderma atroviride, Heteroconium chaetospira, Claroideoglomus etunicatum, and Glomus intraradices [6,25,36-38]. These microorganisms, inhabiting the rhizosphere soil and colonizing plant roots, belong to the PGPM (plant growth-promoting microorganisms) group [6,23,24,33-35]. Among them, we can distinguish PGPR (plant growth-promoting rhizobacteria) $[23,24,33]$ and PGPF (plant growth-promoting fungi) $[6,25,38]$. PGPMs also have the ability to limit the growth and development of phytopathogens.

Phytopathogenic bacteria and fungi can be effectively reduced in the soil environment by PGPRs and PGPFs, which produce substances toxic to various pathogens. These include antibiotics, siderophores and hydrolytic enzymes (chitinases, $\beta$-1,3-glucanases, $\beta$ 1,6-glucanases, proteases, cellulases) [39-43]. These substances break down the hyphae and spores of various phytopathogens $[44,45]$. Such abilities were demonstrated, among others, by Pseudomonas spp., Bacillus spp., Clonostachys spp., Myrothecium spp., or Trichoderma spp. [6,40-42]. The antagonistic activity of Trichoderma sp. towards other microorganisms is based on antibiosis, competition, and mycoparasitism [43-47].

Beneficial microorganisms and natural substances are used in the production of commercial preparations recommended for the cultivation of various plant species $[6,7,27,28]$. Such preparations include, among others, Biosept Active (a.s.- grapefruit extract), Trianum P (containing Trichoderma harzianum Rifai T-22 spores) and Timorex Gold 24 EC (based on tea tree oil) $[6,48,49]$. Tea tree oil is an extract obtained from Melaleuca alternifolia L. [48-50]. Its components (1,8-cineole, gamma-terpinene, terpinen-4-ol, p-cymene and sesquiterpenes) have antiseptic properties [50,51]. Tea tree oil breaks down cell membranes and organelles of phytopathogenic bacteria and fungi [48,52]. It effectively controls fungi of the genera Botrytis, Fusarium, Penicillium, Aspergillus, Colletotrichum, and Alternaria [53,54]. Extract from grapefruit pulp and seeds (Citrus paradisi Macfad.) contains glycosides (mainly naringin), endogenous flavonoids, coumarins, furanocoumarins, and terpenes [49,55]. They have antiviral, antibacterial and antifungal properties. They inhibit spore germination, growth of infectious hyphae, and mycelium development [52,56]. Grapefruit extract exhibits high efficiency in protecting ornamental plants and vegetables from fusariosis mold (Fusarium spp., Fusarium oxysporum f. sp. cyclaminis), alternariosis (Alternaria spp.), phytophtoriosis (Phytophthora cinnamomi, P. cryptogea, P. infestans), and gray mold (Botrytis cinerea) $[7,48,57-60]$.

The aim of the study was to establish the effect of biostimulants (grapefruit extract, tea tree oil and Trichoderma harzianum Rifai T-22) on the antagonistic activity of microorganisms in the rhizosphere soil of scorzonera (Scorzonera hispanica L.) and on the health status of this plant in field cultivation.

\section{Materials and Methods}

\subsection{Field Experiment}

The experiments were carried out in 2014-2016 in south-eastern Poland (Lublin region; $51^{\circ} 23^{\prime} \mathrm{N}, 22^{\circ} 56^{\prime} \mathrm{E}$ ), on Haplic Luvisol soil formed from silty medium loams. The subject of the research was scorzonera (Scorzonera hispanica L.) cv. "Duplex" cultivated on ridges. The experiment involved scorzonera cultivation after winter wheat (forecrop). Disking was performed after wheat harvest, and deep ploughing before winter (about $25 \mathrm{~cm}$ ). Before scorzonera sowing, the soil contained 1.06-1.15\% of humus in the 0-20 cm depth and was characterized by slightly acidic ( $\mathrm{pH}$ in $1 \mathrm{M} \mathrm{KCl}-5.76-5.90)$. The amount of available phosphorus, potassium, and magnesium was as follows: $\mathrm{P}-146.8 ; \mathrm{K}-111.5 ; \mathrm{Mg}-$ $102.9 \mathrm{mg} / \mathrm{kg}$ soil. NPK mineral fertilization was applied in the spring in the amount of: 100:50:100 kg/ha. Cultivator treatment and harrowing was performed after the application of mineral fertilizers. The experiment was set up as a completely randomized block design in 4 replicates. The area of each experimental plot was $14 \mathrm{~m}^{2}$. The experiment was established in the first 10-day period of May. Scorzonera seeds were sown to a depth of $3 \mathrm{~cm}$, in rows every $50 \mathrm{~cm}$, in the amount of $12 \mathrm{~kg} / \mathrm{ha}$. The plants were harvested in the second half of October. 
Biostimulants and a fungicide were used for pre-sowing treatment of scorzonera seeds. These were the following preparations: Biosept Active (based on grapefruit seed and pulp extract) produced by Cintamani Poland; Timorex Gold 24 EC (based on essential tea tree oil) produced by Biomor Israel Ltd., Katzerin, Israel; Trianum P (containing spores of Trichoderma harzianum Rifai T-22) produced by Koppert BV, Veilingweg, Netherlands and the fungicide Zaprawa Nasienna T 75 DS/WS (a.s.- -tiuram 75\%) produced by Organika-Azot in Jaworzno, Poland. Untreated seeds were considered controls. The preparations were applied according to the manufacturers' recommendations: Biosept Active-10 mL/ kg seeds, Trianum P-50 g/kg seeds, Timorex Gold 24 EC $-150 \mathrm{~mL} / \mathrm{kg}$ seeds and fungicide Zaprawa Nasienna T 75 DS/WS $-5 \mathrm{~g} / \mathrm{kg}$ seeds. During three growing seasons both scorzonera plants and their rhizosphere soil were analyzed. The number of scorzonera plants on individual plots and the proportion of plants with visible disease symptoms were determined in each year of the study at the BBCH 14-15 stage (4-5 leaf stage).

Both scorzonera plants with necrosis symptoms on the roots and the infected roots obtained after scorzonera harvest were subjected to laboratory mycological analysis. This analysis, described in detail in Section 2.2, was performed in accordance with the methods used in mycological and phytopathological research. Mycological analysis allowed to determine the quantitative and qualitative composition of the fungi colonizing scorzonera roots. In parallel, microbiological analysis of the rhizosphere soil, i.e., soil directly adhering to the roots of the tested plants, was performed. This analysis is described in detail in Section 2.3 and it was also performed in accordance with the methods applied in mycological and phytopathological research. The number of rhizospheric populations of fungi and bacteria, including Pseudomonas and Bacillus bacteria, was determined based on the microbiological analysis of the soil. Moreover, the isolated rhizosphere fungi were identified to the genus and species. The next stage of the research were laboratory tests, which determined the antagonistic effect of rhizobacterial isolates (Pseudomonas sp. and Bacillus sp.) and the influence of selected saprotrophic rhizosphere fungal species on selected fungi pathogenic for scorzonera. The studied saprophotophic fungi included the following species: Acremonium rutilum, Albifimbria verrucaria, Penicillium chermesinum, Penicillium decumbens, Penicillium simplicissimum, Clonostachys rosea, Talaromyces flavus, Trichoderma sp. and Trichothecium roseum. The tested pathogenic fungi included Alternaria scorzonerae, Fusarium culmorum, Fusarium oxysporum and Rhizoctonia solani. These laboratory tests determining the antagonistic activity of the studied rhizosphere fungi and bacteria were performed in accordance with the methodology used in phytopathological studies. These methods are described in detail in Section 2.4 (antagonistic activity of rhizosphere fungi) and Section 2.5 (antagonistic activity of rhizosphere bacteria).

\subsection{Mycological Analysis of Plants}

In each growing season, the health status of scorzonera plants and roots was determined. According to the method described for Daucus carota, 50 scorzonera seedlings (BBCH 14-15) with disease symptoms were randomly collected for laboratory mycological analysis from each variant of the experiment. After scorzonera harvest, 50 randomly selected roots (BBCH 49) with necrotic and etiological signs were also analyzed. The mycological analysis was conducted according to the method described by Patkowska et al. [6] for carrot. On this basis, the species and quantitative composition of fungi infecting scorzonera roots was determined at different development stages, i.e., BBCH 14-15 and BBCH 49.

Mycological analysis: The infected scorzonera roots were rinsed for 30 min under running tap water, subsequently disinfected in $1 \%$ sodium hypochlorite. Surface-disinfected plant material was rinsed three times for three minutes in sterile distilled water. Threemillimeter fragments were cut from the thus prepared plant material and placed in $9-\mathrm{cm}$ sterile Petri dishes on SNA (selective nutrient agar) medium with the following composition: $38 \mathrm{~g}$ saccharose, $0.7 \mathrm{~g} \mathrm{NH}_{4} \mathrm{NO}_{3}, 0.3 \mathrm{~g} \mathrm{KH}_{2} \mathrm{PO}_{4}, 0.3 \mathrm{~g} \mathrm{MgSO} 4 \times 7 \mathrm{H}_{2} \mathrm{O}, 20 \mathrm{~g}$ agar and trace quantities of $\mathrm{FeCl}_{3} \times 6 \mathrm{H}_{2} \mathrm{O}, \mathrm{ZnSO}_{4} \times 7 \mathrm{H}_{2} \mathrm{O}, \mathrm{CuSO}_{4} \times 7 \mathrm{H}_{2} \mathrm{O}$ and $\mathrm{MnSO}_{4} \times 5$ 
$\mathrm{H}_{2} \mathrm{O}$ In each of the experimental variants, 100 fragments of infected scorzonera roots were examined. After 10-12 days, fungal cultures were transferred to sterile Petri dishes with PDA (potato dextrose agar) medium and incubated at $20-22{ }^{\circ} \mathrm{C}$, with $12 \mathrm{~h}$ light $/ 12 \mathrm{~h}$ dark cycles. After 14-24 days, fungal colonies were identified to the genus and species level (morphological structures: Mycelium, conidiophores and conidia) under a microscope, based on the keys and monographs listed by Patkowska and Krawiec [61]. Moreover, fungi of the genus Penicillium were identified on Czapek-Dox and Malt media. SNA and PDA media were used for Fusarium sp. The number and percentage of occurrence of the recovered fungal species were calculated.

\subsection{Microbiological Analysis of Rhizosphere Soil}

Microbiological laboratory analysis of rhizosphere soil was performed according to the method described by Patkowska et al. [6] for carrot, and by Czaban et al. [62] for winter wheat. For this purpose, ten weeks after sowing scorzonera seeds, 10 plants were dug out of each experimental plot, i.e., 40 plants in each variant of the experiment. The soil directly adhering to scorzonera roots (i.e., rhizosphere soil) was shaken off into sterile Petri dishes. Under sterile laboratory conditions, $10 \mathrm{~g}$ of the soil was weighed from each soil sample for further analysis (4 replicates for each experimental treatment).

Soil solutions were prepared in laboratory conditions from $10 \mathrm{~g}$ weighed amounts with dilutions from $10^{-1}$ to $10^{-7}$, according to the method described by Patkowska [63]. Martin's medium (10 g glucose, 5 g peptone, $1.0 \mathrm{~g} \mathrm{KH}_{2} \mathrm{PO}_{4}, 0.5 \mathrm{~g} \mathrm{MgSO}_{4} \times 7 \mathrm{H}_{2} \mathrm{O}, 30 \mathrm{mg}$ streptomycin, $30 \mathrm{mg}$ bengal rose, $15 \mathrm{~g}$ agar) was used to determine the total number of fungi. The total size of bacterial population and the abundance of bacteria from the genera Pseudomonas and Bacillus were determined on nutrient agar (Pseudomonas agar F and Tryptic soy agar, respectively). For Bacillus sp. isolation, soil dilutions were heated for $20 \mathrm{~min}$ at $80^{\circ} \mathrm{C}$. After incubation $\left(2-5\right.$ days at $\left.20-22^{\circ} \mathrm{C}\right)$, the number of fungal and bacterial colonies was determined and converted into CFU/g soil DW (colony forming units/g soil dry weight). The obtained fungal colonies were transferred to sterile Petri dishes with PDA medium and incubated for the next $2-3$ weeks at $20-22{ }^{\circ} \mathrm{C}$. After that time, the fungi were microscopically determined to the genus and species based on the keys and monographs. The number of obtained species of fungi was calculated.

\subsection{Antagonistic Activity of Rhizosphere Fungi from Scorzonera Cultivation}

Antagonistic effect of selected saprotrophic fungi isolated from the scorzonera rhizosphere (Acremonium rutilum, Albifimbria verrucaria, Penicillium chermesinum, Penicillium decumbens, Penicillium simplicissimum, Clonostachys rosea, Talaromyces flavus, Trichoderma sp., and Trichothecium roseum) against selected pathogenic fungi for this plant (Alternaria scorzonerae, Fusarium culmorum, Fusarium oxysporum and Rhizoctonia solani) was determined based on the methods described by Jamiołkowska et al. [64] and Patkowska and BłażewiczWoźniak [65]. For this purpose, laboratory tests were carried out in vitro using Petri dishes with sterile PDA (potato dextrose agar) medium. In the central part of the dish, two 3-mm fungi inocula were grafted $2 \mathrm{~cm}$ apart. Colonies of the studied fungi grown from one 3-mm inoculum, grafted in the middle of the dish served as controls. The cultures were grown in an incubator at $24^{\circ} \mathrm{C}$. The biotic effect was established after 10 days of growth. Each experimental variants included 4 dishes, which were treated as replicates.

The antagonistic activity is expressed as the individual biotic effect (IBE), i.e., the effect of one isolate of a given species on pathogens. IBE multiplied by the species frequency gives the general biotic effect (GBE), considered as the effect of all isolates on the pathogen. The summary biotic effect (SBE) is obtained after adding all GBEs. The SBE was a measure of antagonistic activity of saprotrophic fungi against the studied pathogens in the scorzonera rhizosphere. It was calculated for each variant of the field experiment. 


\subsection{Antagonistic Activity of Pseudomonas sp. and Bacillus sp. Rhizobacteria from Scorzonera Cultivation}

The antagonistic activity of rhizobacteria was determined using research methods applied for Daucus carota and described by Patkowska and Błażewicz-Woźniak [65]. Considering the variants of the field experiment, isolates of Pseudomonas sp. and Bacillus sp. obtained from the scorzonera rhizosphere were tested each year of the study against frequently isolated fungi pathogenic for this plant, such as Alternaria scorzonerae, Fusarium culmorum, Fusarium oxysporum, and Rhizoctonia solani. The experiments were carried out in Petri dishes with PDA (potato dextrose agar) medium, onto which, individual bacterial isolates were inoculated in the central part of the dish in the form of two parallel lines, $4 \mathrm{~cm}$ apart. The fungus was inoculated in the center of the dish after two days of incubation of bacteria at $22{ }^{\circ} \mathrm{C}$. The inoculum consisted of 3-mm mycelium-overgrown agar discs cut from 14-day-old fungal cultures grown on PDA at $24^{\circ} \mathrm{C}$. The controls were fungal colonies growing in Petri dishes with PDA medium without the bacterial isolate. Four replicates were included for each bacterial isolate and control. Further incubation was conducted at $24{ }^{\circ} \mathrm{C}$. After 10 days of co-culture, the inhibition zone and diameter of the fungus colony were measured (in $\mathrm{mm}$ ) and the percentage of growth inhibition relative to the control colony was calculated.

The antagonistic effect of bacteria was determined on the basis of a five-point scale, taking into account the inhibition zone of fungal colony growth. These were: $0^{\circ}-$ no inhibition zone, $1^{\circ}-1-2 \mathrm{~mm}$ inhibition zone, $2^{\circ}-3-5 \mathrm{~mm}$ inhibition zone, $3^{\circ}-6-10 \mathrm{~mm}$ inhibition zone, and $4^{\circ}$-inhibition zone over $10 \mathrm{~mm}$. The second factor determining the antagonistic abilities of bacteria was the inhibition of fungal colony growth. A five-point scale was also used for this purpose: $0^{\circ}$-no fungus growth inhibition, $1^{\circ}$-colony growth inhibited to $20 \%, 2^{\circ}$-colony growth inhibited to $50 \%, 3^{\circ}$ —colony growth inhibited to $80 \%$, 4 - colony growth inhibited to $100 \%$. The value of the individual antagonistic activity (A) of each bacterial genus multiplied by the number of isolates was defined as general antagonistic activity (B). The total antagonistic activity of Pseudomonas sp. and Bacillus sp. against Alternaria scorzonerae, Fusarium culmorum, Fusarium oxysporum, and Rhizoctonia solani was calculated for each variant of the field experiment.

\subsection{Statistical Analysis}

Results concerning the density of scorzonera plants, health status and the number of rhizosphere fungi and bacteria were statistically analyzed. The means were compared to the use of the least significant differences based on the Tukey's test $(p \leq 0.05)$. Statistical calculations were carried out using Statistica, version 7.1 (StatSoft, Krakow, Poland).

\section{Results}

The emergence and health of scorzonera seedlings after the application of biostimulants was significantly better than in the control (Table 1). The number of scorzonera seedlings in all experimental treatments in individual years of the study ranged from 28.5 to 56 plants $/ \mathrm{m}^{2}$. The highest number of seedlings was found after the application of Trianum P and the fungicide Zaprawa Nasienna T 75 DS/WS (52.2 and 46.5 plants $/ \mathrm{m}^{2}$, respectively). The lowest number of plants grew on the control plots ( 32.3 plants $\left./ \mathrm{m}^{2}\right)$. Biostimulants and the fungicide significantly reduced the occurrence of diseased scorzonera plants. The highest number of infected seedlings was found in control, and the lowest after the application of Trianum P and Zaprawa Nasienna T 75 DS/WS. 
Table 1. Field stand of scorzonera seedlings.

\begin{tabular}{ccccc}
\hline \multirow{2}{*}{$\begin{array}{c}\text { Experimental } \\
\text { Treatment }\end{array}$} & \multicolumn{4}{c}{ Field Stand Per 1 $\mathbf{~}^{\mathbf{2}}$} \\
\cline { 2 - 5 } & $\mathbf{2 0 1 4}$ & $\mathbf{2 0 1 5}$ & $\mathbf{2 0 1 6}$ & Mean \\
\hline Biosept Active & $38.5 \mathrm{~b}$ & $47.0 \mathrm{~b}$ & $46.5 \mathrm{~b}$ & $44.0 \mathrm{~b}$ \\
Timorex Gold 24 EC & $36.0 \mathrm{~b}$ & $44.5 \mathrm{~b}$ & $43.0 \mathrm{~b}$ & $41.2 \mathrm{~b}$ \\
Trianum P & $48.0 \mathrm{a}$ & $52.5 \mathrm{a}$ & $56.0 \mathrm{a}$ & $52.2 \mathrm{a}$ \\
Zaprawa Nasienna & $40.5 \mathrm{~b}$ & $50.0 \mathrm{a}$ & $49.0 \mathrm{a}$ & $46.5 \mathrm{~b}$ \\
T 75 DS/WS & $30.0 \mathrm{c}$ & $38.5 \mathrm{~b}$ & $28.5 \mathrm{c}$ & $32.3 \mathrm{c}$ \\
Control &
\end{tabular}

Values in columns followed by the same letter do not differ significantly at $p \leq 0.05$.

Young scorzonera plants with symptoms of root necrosis were present in all experimental combinations (Figure 1). Similar necrosis symptoms and etiological signs in the form of hyphae, spores or sclerotia were observed on scorzonera roots after harvest (Figures 2-4).

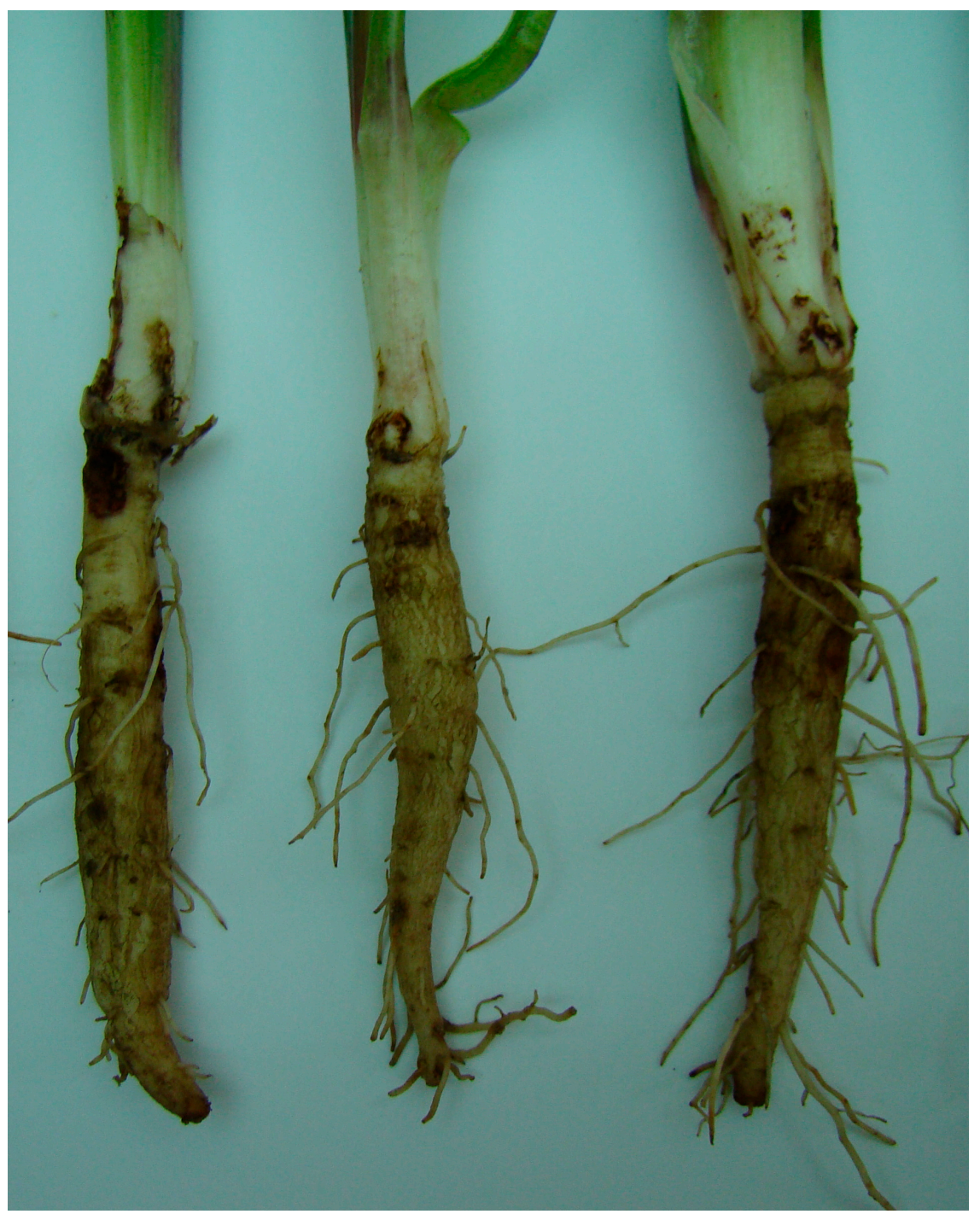

Figure 1. Necrosis on the roots of scorzonera seedlings; (photo by E. Patkowska). 


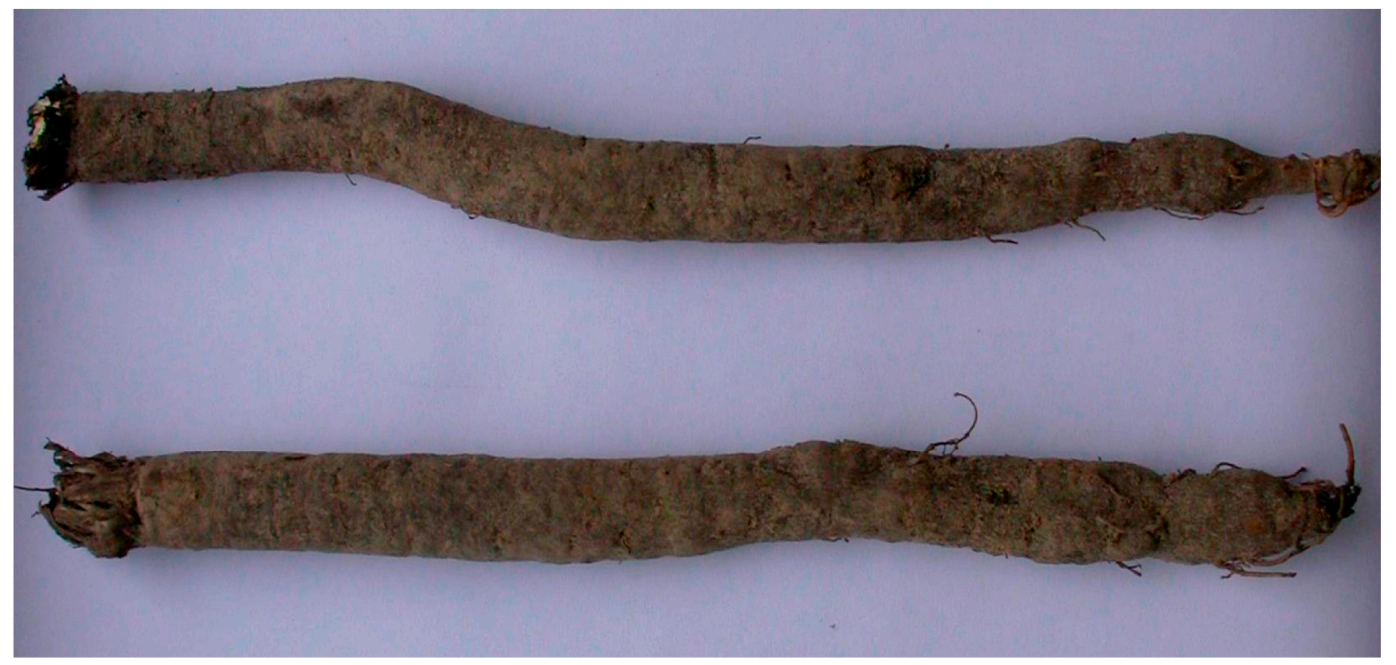

Figure 2. Scorzonera roots after harvest; (photo by E. Patkowska).

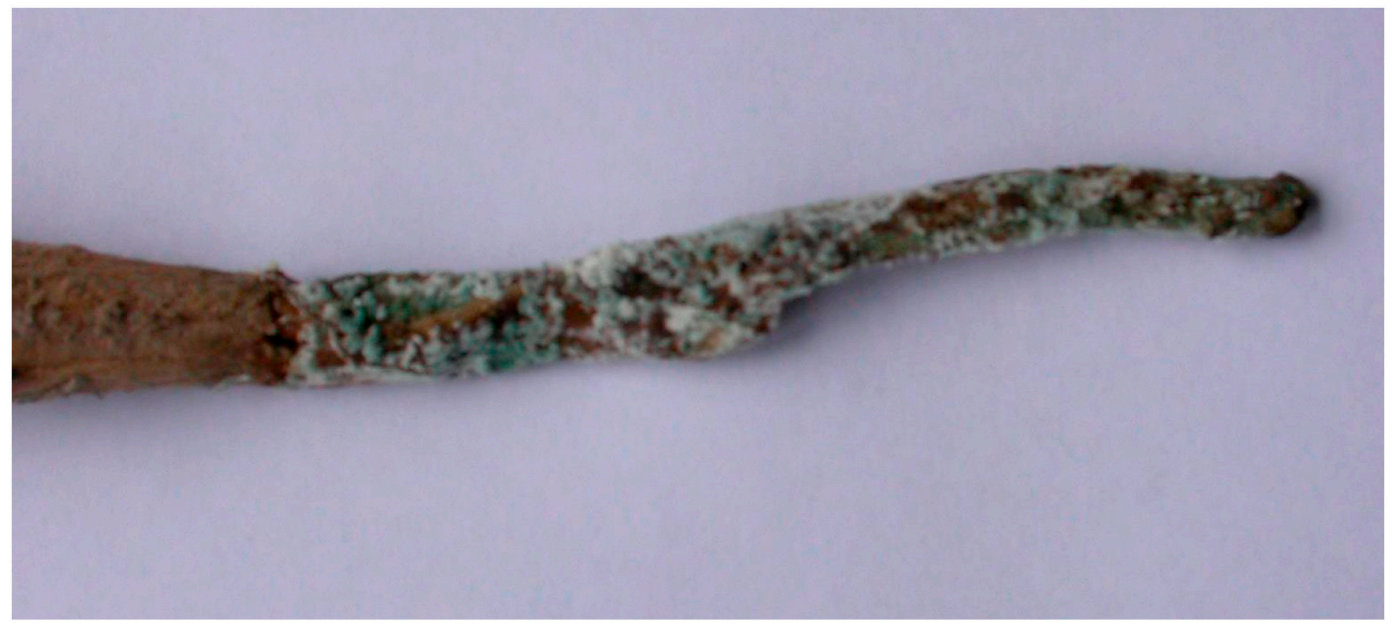

Figure 3. Mycelium and conidia of Penicillium sp. on the scorzonera root (scale 3:1); (photo by E. Patkowska).

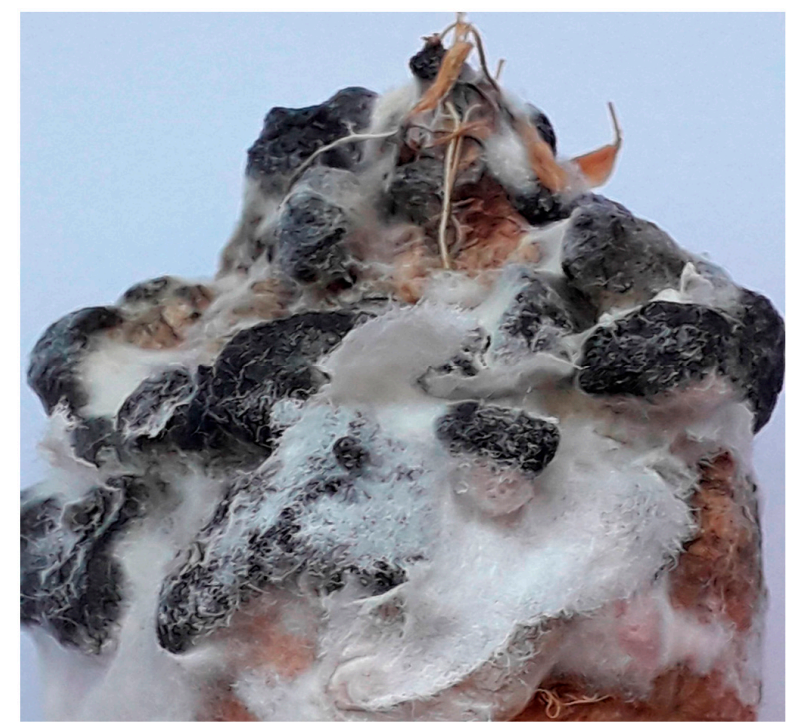

Figure 4. Mycelium and sclerotia of Sclerotinia sclerotiorum on the scorzonera root (scale 3:1); (photo by E. Patkowska). 
As a result of mycological analysis, 1289 colonies of fungi belonging to 13 genera were isolated from the infected scorzonera seedlings (Table 2). After applying Trianum $\mathrm{P}$ or the fungicide, more than twice as much fungi was obtained than from the control plants. Slightly more fungi were isolated when Biosept Active or Timorex Gold 24 EC biostimulants were applied. Among the fungi considered to be pathogenic, Fusarium oxysporum and Rhizoctonia solani were predominant, and their proportion was $18.9 \%$ and $15.1 \%$, respectively (Table 2 ). Moreover, scorzonera seedlings were colonized mainly by Alternaria scorzonerae (8.6\% all isolates), Alternaria alternata (6.6\%), Fusarium culmorum (9.3\%), Neocosmospora solani (6.3\%), and saprotrophic species such as Penicillium janczewskii (4.5\%) and Talaromyces flavus ( $4.8 \%)$.

Table 2. Fungi isolated from diseased scorzonera seedlings (sum 2014-2016).

\begin{tabular}{|c|c|c|c|c|c|c|}
\hline \multirow{2}{*}{ Fungi } & \multicolumn{6}{|c|}{ Number of Isolates/Experimental Treatment } \\
\hline & $I^{*}$ & II & III & IV & $\mathbf{V}$ & Total $(\%)$ \\
\hline Acremonium rutilum W. Gams & 5 & 7 & 3 & 4 & 9 & $28(2.2)$ \\
\hline Alternaria alternata (Fr.) Keissler & 17 & 21 & 8 & 11 & 27 & $84(6.6)$ \\
\hline Alternaria scorzonerae (Aderh.) Loer. & 22 & 28 & 10 & 15 & 36 & $111(8.6)$ \\
\hline Botrytis cinerea Pers. & 6 & 9 & 2 & 4 & 11 & $32(2.5)$ \\
\hline Cladosporium herbarum (Pers.) Link & 7 & 9 & 3 & 5 & 12 & $36(2.8)$ \\
\hline $\begin{array}{c}\text { Cylindrocarpon didymum (Harting) } \\
\text { Wollenw. }\end{array}$ & 10 & 12 & 4 & 7 & 16 & $49(3.8)$ \\
\hline $\begin{array}{c}\text { Clonostachys rosea (Link) Schroers, } \\
\text { Samuels, Seifert }\end{array}$ & 2 & 2 & 3 & - & - & $7(0.5)$ \\
\hline Fusarium culmorum (W.G.Sm.) Sacc. & 23 & 29 & 14 & 18 & 36 & $120(9.3)$ \\
\hline Fusarium oxysporum Schl. & 46 & 54 & 32 & 38 & 74 & $244(18.9)$ \\
\hline Fusarium graminearum Schwabe & 7 & 9 & 4 & 5 & 10 & $35(2.7)$ \\
\hline $\begin{array}{l}\text { Neocosmospora solani (Mart.) L. } \\
\text { Lombard and Crous }\end{array}$ & 16 & 21 & 6 & 10 & 27 & $80(6.3)$ \\
\hline $\begin{array}{c}\text { Hyalocylindrophora rosea (Petch) } \\
\text { Réblová and W. Gams }\end{array}$ & 9 & 11 & 4 & 6 & 14 & $44(3.4)$ \\
\hline Penicillium janczewskii K.W. Zaleski & 12 & 14 & 6 & 8 & 18 & $58(4.3)$ \\
\hline $\begin{array}{c}\text { Penicillium simplicissimum (Oudem.) } \\
\text { Thom }\end{array}$ & 7 & 9 & 3 & 5 & 10 & $34(2.6)$ \\
\hline Penicillium verrucosum Dierckx & 6 & 8 & 4 & 5 & 10 & $33(2.6)$ \\
\hline Rhizoctonia solani J.G. Kühn & 37 & 42 & 27 & 31 & 57 & $194(15.1)$ \\
\hline $\begin{array}{c}\text { Talaromyces flavus (Klöcker) Stolk } \\
\text { and Samson }\end{array}$ & 12 & 15 & 6 & 9 & 19 & $61(4.8)$ \\
\hline Trichoderma sp. & 12 & 12 & 15 & - & - & $39(3.0)$ \\
\hline Total isolates & 256 & 312 & 154 & 181 & 386 & $1289(100)$ \\
\hline
\end{tabular}

I * -Biosept Active, II-Timorex Gold 24 EC, III-Trianum P, IV—Zaprawa Nasienna T 75 DS/WS, V—control.

After harvest, 1664 colonies of fungi belonging to 14 genera were obtained from scorzonera roots with disease symptoms (Table 3). Trianum P and Biosept Active most effectively protected the roots of scorzonera against soil-borne pathogen infections. Timorex Gold 24 EC showed a slightly lower effectiveness. Sclerotinia sclerotiorum, Fusarium oxysporum, Rhizoctonia solani, Fusarium culmorum, and Alternaria scorzonerae were most commonly isolated from diseased scorzonera roots, and their percentage was $21.4 \%, 18.8 \%$, $11.9 \%, 8.2 \%$, and $7.9 \%$, respectively (Table 3 ). The roots of the studied plants were colonized to a lesser extent by Penicillium aurantiogriseum, Penicillium canescens, Cladosporium cladosporioides, Neocosmospora solani and Trichothecium roseum. Additionally, fungi of the genera Botrytis, Aureobasidium, Cylindrocarpon, and Rhizopus were identified. Biostimulants also contributed to the colonization of scorzonera roots by Clonostachys rosea and Trichoderma sp. These microorganisms, known for their antagonistic properties, were not obtained from control or fungicide-protected plants. 
Table 3. Fungi isolated from diseased scorzonera roots after harvest (sum 2014-2016).

\begin{tabular}{|c|c|c|c|c|c|c|}
\hline \multirow{2}{*}{ Fungi } & \multicolumn{6}{|c|}{ Number of Isolates/Experimental Treatment } \\
\hline & $I^{*}$ & II & III & IV & $\mathbf{V}$ & Total (\%) \\
\hline Alternaria alternata (Fr.) Keissler & 9 & 11 & 5 & 7 & 13 & $45(2.7)$ \\
\hline Alternaria scorzonerae (Aderh.) Loer. & 26 & 32 & 13 & 21 & 40 & $132(7.0)$ \\
\hline $\begin{array}{c}\text { Aureobasidium pullulans (de Bary and } \\
\text { Löwenthal) G. Arnaud }\end{array}$ & 6 & 8 & 2 & 4 & 10 & $30(1.8)$ \\
\hline Botrytis cinerea Pers. & 8 & 11 & 3 & 4 & 16 & $42(2.5)$ \\
\hline $\begin{array}{c}\text { Cladosporium cladosporioides (Fresen.) } \\
\text { G.A. de Vries }\end{array}$ & 11 & 15 & 3 & 6 & 21 & $56(3.4)$ \\
\hline $\begin{array}{c}\text { Cylindrocarpon didymum (Harting) } \\
\text { Wollenw. }\end{array}$ & 7 & 10 & 3 & 5 & 12 & $37(2.2)$ \\
\hline $\begin{array}{c}\text { Clonostachys rosea (Link) Schroers, } \\
\text { Samuels, Seifert }\end{array}$ & 4 & 3 & 5 & - & - & $12(0.7)$ \\
\hline Fusarium culmorum (W.G.Sm.) Sacc. & 27 & 32 & 17 & 22 & 38 & $136(8.2)$ \\
\hline Fusarium oxysporum Schl. & 59 & 71 & 41 & 49 & 92 & $312(18.8)$ \\
\hline $\begin{array}{l}\text { Neocosmospora solani (Mart.) L. } \\
\text { Lombard and Crous }\end{array}$ & 9 & 11 & 4 & 6 & 15 & $45(2.7)$ \\
\hline Penicillium aurantiogriseum Dierckx & 15 & 18 & 8 & 11 & 25 & $77(4.7)$ \\
\hline Penicillium canescens Sopp & 11 & 13 & 5 & 8 & 16 & $53(3.2)$ \\
\hline Rhizoctonia solani J.G. Kühn & 38 & 46 & 24 & 31 & 60 & $199(11.9)$ \\
\hline Rhizopus stolonifer (Ehrenb.) Vuill., & 6 & 10 & 1 & 2 & 14 & $33(2.0)$ \\
\hline Sclerotinia sclerotiorum (Lib.) de Bary & 68 & 79 & 50 & 57 & 102 & $356(21.4)$ \\
\hline Trichoderma sp. & 15 & 13 & 15 & - & - & $43(2.5)$ \\
\hline Trichothecium roseum (Pers.) Link & 10 & 15 & 4 & 6 & 21 & $56(3.4)$ \\
\hline Total isolates & 329 & 398 & 203 & 239 & 495 & $1664(100)$ \\
\hline
\end{tabular}

I *-Biosept Active, II-Timorex Gold 24 EC, III-Trianum P, IV—Zaprawa Nasienna T 75 DS/WS, V—control.

The number of colonies of scorzonera rhizosphere microorganisms isolated in laboratory conditions on selective media varied. Both the biostimulants and fungicide reduced the population of rhizosphere fungi. Their average number in these variants of the experiment ranged from $3.82 \times 10^{3}$ to $6.30 \times 10^{3} \mathrm{CFU} / \mathrm{g}$ soil DW (Table 4). However, it was statistically significantly smaller than in control $\left(9.38 \times 10^{3} \mathrm{CFU} / \mathrm{g}\right.$ soil DW). Trianum $\mathrm{P}$ and Zaprawa Nasienna T 75 DS/WS were most effective in reducing the occurrence of rhizospheric fungi. Biosept Active and Timorex Gold 24 EC were slightly less effective in limiting the development of the fungal population, as their abundance in the scorzonera rhizosphere was on average $6.31 \times 10^{3}$ and $6.60 \times 10^{3} \mathrm{CFU} / g$ soil DW, respectively. These values were statistically significantly different from control. The number of colonies of rhizobacteria in these variants of the experiment ranged from $2.36 \times 10^{6}$ (control) to $8.12 \times$ $10^{6} \mathrm{CFU} / \mathrm{g}$ soil DW (Zaprawa Nasienna T 75 DS/WS). Pseudomonas sp. bacteria colonized scorzonera roots to a lesser extent compared to Bacillus sp. The population size of the genus Pseudomonas ranged on average from $0.53 \times 10^{6}$ to $2.95 \times 10^{6} \mathrm{CFU} / \mathrm{g}$ soil DW, and the bacteria of the genus Bacillus ranged from $0.48 \times 10^{6}$ to $4.55 \times 10^{6} \mathrm{CFU} / \mathrm{g}$ soil DW. Biostimulants, especially Trianum P and Biosept Active, favored the development of the studied rhizobacteria. The number of these microorganisms after the application of biostimulants was statistically significantly higher than in control. 
Table 4. Number of fungi and bacteria isolated from the rhizosphere of scorzonera.

\begin{tabular}{|c|c|c|c|c|c|c|c|c|c|c|c|c|c|c|c|c|}
\hline \multirow{2}{*}{$\begin{array}{c}\text { Experimental } \\
\text { Treatment }\end{array}$} & \multicolumn{4}{|c|}{ Total CFU of Fungi $\left(10^{3} / \mathrm{g}\right.$ Soil DW) } & \multicolumn{4}{|c|}{ Total CFU of Bacteria ( $10^{6} / \mathrm{g}$ Soil DW) } & \multicolumn{4}{|c|}{ CFU of Pseudomonas sp. $\left(10^{6} / \mathrm{g}\right.$ Soil DW) } & \multicolumn{4}{|c|}{ CFU of Bacillus sp. (10\%/g Soil DW) } \\
\hline & 2014 & 2015 & 2016 & Mean & 2014 & 2015 & 2016 & Mean & 2014 & 2015 & 2016 & Mean & 2014 & 2015 & 2016 & Mean \\
\hline Biosept Active & $6.38 \mathrm{~b}$ & $5.92 \mathrm{~b}$ & $6.64 \mathrm{~b}$ & $6.31 \mathrm{~b}$ & $5.93 \mathrm{~b}$ & $4.26 \mathrm{~b}$ & $5.30 \mathrm{~b}$ & $5.16 \mathrm{~b}$ & $1.16 \mathrm{~b}$ & $1.90 \mathrm{a}$ & $1.86 \mathrm{~b}$ & $1.64 \mathrm{bc}$ & $2.14 \mathrm{~b}$ & $2.00 \mathrm{~b}$ & $3.06 \mathrm{~b}$ & $2.40 \mathrm{~b}$ \\
\hline $\begin{array}{c}\text { Timorex Gold } 24 \text { EC } \\
\text { Trianum P }\end{array}$ & $\begin{array}{l}6.84 \mathrm{~b} \\
4.25 \mathrm{c}\end{array}$ & $\begin{array}{l}6.04 \mathrm{~b} \\
3.16 \mathrm{c}\end{array}$ & $\begin{array}{l}6.92 \mathrm{~b} \\
4.06 \mathrm{c}\end{array}$ & $\begin{array}{l}6.60 \mathrm{~b} \\
3.82 \mathrm{c}\end{array}$ & $\begin{array}{l}5.22 \mathrm{~b} \\
8.02 \mathrm{a}\end{array}$ & $\begin{array}{l}4.12 \mathrm{~b} \\
7.45 \mathrm{a}\end{array}$ & $\begin{array}{l}5.12 \mathrm{~b} \\
8.32 \mathrm{a}\end{array}$ & $\begin{array}{l}4.82 \mathrm{~b} \\
7.93 \mathrm{a}\end{array}$ & $\begin{array}{l}1.12 \mathrm{~b} \\
2.94 \mathrm{a}\end{array}$ & $\begin{array}{l}1.82 \mathrm{a} \\
2.46 \mathrm{a}\end{array}$ & $\begin{array}{l}1.55 \mathrm{~b} \\
3.00 \mathrm{a}\end{array}$ & $\begin{array}{l}1.50 \mathrm{c} \\
2.80 \mathrm{a}\end{array}$ & $\begin{array}{l}1.95 \mathrm{~b} \\
4.15 \mathrm{a}\end{array}$ & $\begin{array}{l}1.88 \mathrm{~b} \\
3.92 \mathrm{a}\end{array}$ & $\begin{array}{l}2.85 \mathrm{~b} \\
4.91 \mathrm{a}\end{array}$ & $\begin{array}{l}2.22 \mathrm{~b} \\
4.32 \mathrm{a}\end{array}$ \\
\hline Zaprawa Nasienna & $4.34 \mathrm{c}$ & $3.28 \mathrm{c}$ & $4.15 \mathrm{c}$ & $3.92 \mathrm{c}$ & $8.14 \mathrm{a}$ & $7.68 \mathrm{a}$ & $\begin{array}{l}8.52 \mathrm{a} \\
8.54 \mathrm{a}\end{array}$ & $8.12 \mathrm{a}$ & $3.05 \mathrm{a}$ & $2.66 \mathrm{a}$ & $3.14 \mathrm{a}$ & $2.95 \mathrm{a}$ & $4.38 \mathrm{a}$ & $3.96 \mathrm{a}$ & $5.32 \mathrm{a}$ & $4.55 \mathrm{a}$ \\
\hline $\begin{array}{c}\text { T } 75 \text { DS/WS } \\
\text { Control }\end{array}$ & $9.55 \mathrm{a}$ & $8.82 \mathrm{a}$ & $9.76 \mathrm{a}$ & 9.38 a & $2.68 \mathrm{c}$ & $2.05 \mathrm{c}$ & $2.35 \mathrm{c}$ & $2.36 \mathrm{c}$ & $0.94 \mathrm{~b}$ & $0.14 \mathrm{~b}$ & $0,50 \mathrm{c}$ & $0.53 \mathrm{~d}$ & $0.62 \mathrm{c}$ & $0.28 \mathrm{c}$ & $0.53 \mathrm{c}$ & $0.48 \mathrm{c}$ \\
\hline
\end{tabular}

Values in columns followed by the same letter do not differ significantly at $p \leq 0.05$. 
Species and quantitative composition of rhizosphere fungi was different and depended on the biostimulants or fungicide used (Table 5). A total of 960 colonies of pathogenic or saprotrophic fungi were isolated from the scorzonera rhizosphere. They belonged to 22 genera. Fungi considered pathogenic were most numerous in the rhizosphere of control plants. The smallest number of them was found after the application of the Trianum P or Zaprawa Nasienna T 75 DS/WS. The rhizosphere soil of control plants was characterized by the greatest biodiversity of microorganisms, from which a total of 295 isolates were obtained. Nevertheless, the number of fungi with antagonistic properties was the lowest in this experimental combination. Timorex Gold 24 EC, Trianum P and Biosept Active reduced the occurrence of fungi in the scorzonera rhizosphere, especially those considered pathogenic. From these experimental combinations, 250, 157 and 144 isolates were obtained, respectively. Various species of the genera Albifimbria, Alternaria, Aspergillus, Chaetomium, Cladosporium, Clonostachys, Fusarium, Penicillium, Rhizoctonia, Rhizopus, Sclerotinia, Talaromyces, Trichothecium, and Trichoderma were frequently isolated. Fusarium oxysporum, Rhizoctonia solani, Penicillium spp. (including P. chermesinum, P. decumbens and $P$. simplicissimum) and Trichoderma sp. were dominant and their proportion was $21 \%, 12.4 \%$, $10.5 \%$ and $8.4 \%$ of all isolates, respectively (Table 5). Moreover, the scorzonera rhizosphere was inhabited to a lesser extent by Rhizopus stolonifer, Sclerotinia sclerotiorum, Albifimbria verrucaria, Cladosporium herbarum, Fusarium culmorum, and Clonostachys rosea.

Table 5. Fungi isolated from the rhizosphere of scorzonera (sum 2014-2016).

\begin{tabular}{|c|c|c|c|c|c|c|}
\hline \multirow{2}{*}{ Fungi } & \multicolumn{6}{|c|}{ Number of Isolates/Experimental Treatment } \\
\hline & $I^{*}$ & II & III & IV & $\mathbf{V}$ & Total $(\%)$ \\
\hline Acremonium rutilum W. Gams & 1 & 3 & 3 & 2 & 5 & $14(1.4)$ \\
\hline $\begin{array}{c}\text { Albifimbria verrucaria (Alb. and Schwein.) L. } \\
\text { Lombard and Crous }\end{array}$ & 7 & 13 & 16 & 4 & 1 & $41(4.3)$ \\
\hline Alternaria alternata (Fr.) Keissler & 1 & 2 & 1 & - & 3 & $7(0.7)$ \\
\hline Alternaria scorzonerae (Aderh.) Loer. & 3 & 4 & 1 & 3 & 7 & $18(1.9)$ \\
\hline Arthrinium phaeospermum (Corda) M.B. Ellis & - & - & - & - & 4 & $4(0.4)$ \\
\hline Aspergillus fumigatus Fresen. & 2 & 4 & - & - & 8 & $14(1.4)$ \\
\hline Botrytis cinerea Pers. & 1 & 2 & - & - & 5 & $8(0.8)$ \\
\hline Chaetomium piluliferum J. Daniels & 6 & 10 & 3 & 4 & 15 & $38(4.0)$ \\
\hline Cladosporium cladosporioides (Fresen.) G.A. de Vries & - & 2 & - & - & 5 & $7(0.7)$ \\
\hline Cladosporium herbarum (Pers.) Link & 7 & 11 & 2 & 4 & 16 & $40(4.2)$ \\
\hline Clonostachys rosea (Link) Schroers, Samuels, Seifert & 4 & 12 & 16 & 3 & 1 & $36(3.8)$ \\
\hline $\begin{array}{c}\text { Dipodascus geotrichum (E.E. Butler and L.J. } \\
\text { Petersen) Arx }\end{array}$ & 1 & 3 & - & - & 7 & $11(1.2)$ \\
\hline Fusarium avenaceum (Fr.) Sacc. & - & 2 & - & - & 4 & $6(0.6)$ \\
\hline Fusarium culmorum (W.G.Sm.) Sacc. & 8 & 9 & 4 & 6 & 12 & $39(4.1)$ \\
\hline Fusarium graminearum Schwabe & - & 1 & - & - & 3 & $4(0.4)$ \\
\hline Fusarium oxysporum Schl. & 37 & 43 & 25 & 31 & 66 & $202(21.0)$ \\
\hline Mucor hiemalis Wehmer & - & 5 & - & 4 & 14 & $23(2.4)$ \\
\hline $\begin{array}{c}\text { Neocosmospora solani (Mart.) L. Lombard and } \\
\text { Crous }\end{array}$ & 1 & 4 & - & 1 & 9 & $15(1.6)$ \\
\hline Penicillium chermesinum Biourge & 6 & 14 & 11 & 8 & 8 & $47(4.9)$ \\
\hline Penicillium decumbens Thom & 5 & 15 & 11 & 6 & 3 & $40(4.2)$ \\
\hline Penicillium simplicissimum (Oudem.) Thom & - & 4 & 3 & - & 7 & $14(1.4)$ \\
\hline Rhizoctonia solani J.G. Kühn & 22 & 28 & 12 & 16 & 41 & $119(12.4)$ \\
\hline Rhizopus stolonifer (Ehrenb.) Vuill. & 10 & 14 & 4 & 6 & 20 & $54(5.6)$ \\
\hline Sarocladium kiliense (Grütz) Summerb. & - & 1 & - & - & 3 & $4(0.4)$ \\
\hline Sclerotinia sclerotiorum (Lib.) de Bary & 8 & 11 & 4 & 6 & 15 & $44(4.6)$ \\
\hline Talaromyces flavus (Klöcker) Stolk and Samson & - & 3 & - & 1 & 7 & $11(1.1)$ \\
\hline Torula herbarum (Pers.) Link & - & - & - & - & 3 & $3(0.3)$ \\
\hline Trichoderma sp. & 11 & 25 & 34 & 8 & 2 & $80(8.4)$ \\
\hline Trichothecium roseum (Pers.) Link & 3 & 5 & 7 & 1 & 1 & $17(1.8)$ \\
\hline Total isolates & 144 & 250 & 157 & 114 & 295 & $960(100)$ \\
\hline
\end{tabular}


In vitro tests (Figure 5) allowed to determine the number of antagonistic rhizosphere bacteria (Pseudomonas sp. and Bacillus sp.) and fungi (Acremonium rutilum, Albifimbria verrucaria, Penicillium spp., Clonostachys rosea, Talaromyces flavus, Trichoderma sp., and Trichothecium roseum) against the fungi pathogenic for scorzonera (Alternaria scorzonerae, Fusarium culmorum, Fusarium oxysporum, and Rhizoctonia solani). Biostimulants, especially Timorex Gold 24 EC and Trianum P, stimulated the development of antagonists in the rhizosphere of the tested plant. The most antagonistic bacteria and fungi were obtained after their application (Figure 6a-d). Slightly less antagonists were found after the application of Biosept Active (Pseudomonas sp.-21 isolates, Bacillus sp.-11 isolates, total number of fungi-37 isolates). The lowest number of antagonistic Pseudomonas sp. (13 isolates) and Bacillus sp. (5 isolates) were obtained from the rhizosphere of the control plants. Among the antagonistic bacteria, Pseudomonas sp. was dominant, and among fungi: Trichoderma sp., Penicillium spp., Clonostachys rosea and Albifimbria verrucaria (Figure $6 \mathrm{a}, \mathrm{c})$. The lowest number of these fungi were obtained after using the fungicide.

Rhizosphere fungi and bacteria showed different antagonistic activity against the tested pathogens (Tables 6 and 7). The lowest antagonistic activity of fungi was found in control, and the highest after Trianum P and Timorex Gold 24 EC application (Table 6). Saprotrophic fungi inhibited the growth of Fusarium culmorum and Fusarium oxysporum the least. The highest antagonistic activity was recorded against Alternaria scorzonerae. The summary biotic effect (SBE) for this species, after Timorex Gold 24 EC and Trianum $\mathrm{P}$ application, was +470 and +583 , respectively. Biosept Active showed slightly lower effectiveness in stimulating antagonists to limit the growth of Fusarium oxysporum, Fusarium culmorum, Alternaria scorzonerae and Rhizoctonia solani, because the summary biotic effect against these fungi was: $+150,+168,+200$ and +276 , respectively. In the case of the fungicide, these values were also lower compared to biostimulants, but higher than in control. Among the tested preparations, Timorex Gold 24 EC and Trianum P biostimulants were the most effective in stimulating the tested saprotrophic fungi to limit the growth and development of Fusarium culmorum, Rhizoctonia solani, and Fusarium oxysporum. Among all the tested saprotrophic fungi, the highest individual biotic effect (IBE) was recorded for Trichoderma sp., Clonostachys rosea, Trichothecium roseum and Albifimbria verrucaria. Trichoderma sp. fungi demonstrated the highest antagonistic activity against all pathogenic fungi tested $(\mathrm{IBE}=+8)$.

The antagonistic activity of bacteria Pseudomonas sp. and Bacillus sp., isolated from the scorzonera rhizosphere, towards the analyzed pathogenic fungi Alternaria scorzonerae, Fusarium culmorum, Fusarium oxysporum, and Rhizoctonia solani was different (Table 7 and Figure 7). Pseudomonas sp. showed a greater individual and total antagonistic activity than Bacillus sp. The applied preparations effectively simulated rhizobacteria to limit the growth of pathogenic fungi. Trianum P and Timorex Gold 24 EC showed the greatest effectiveness. The total antagonistic activity of the tested bacteria against all analyzed fungi, after the application of these biostimulants, was 724 and 410, respectively (Table 7). Biosept Active was slightly less effective. The lowest total antagonistic activity of Pseudomonas sp. and Bacillus sp. was recorded after the application of Zaprawa Nasienna T 75 DS/WS and in control. Bacillus sp. and Pseudomonas sp. inhibited the growth and development of Alternaria scorzonerae most effectively, Fusarium culmorum and Rhizoctonia solani slightly less, and Fusarium oxysporum the least effectively. The general antagonistic activity of the tested rhizobacteria against Alternaria scorzonerae ranged from 36 (control) to 231 (Trianum P). These values for Fusarium culmorum and Rhizoctonia solani were similar and ranged from 36 to 181 and from 23 to 181, respectively. The general antagonistic activity of Pseudomonas sp. and Bacillus sp. bacteria against Fusarium oxysporum was the lowest and ranged from 23 (control) to 131 (Trianum P) (Table 7). 


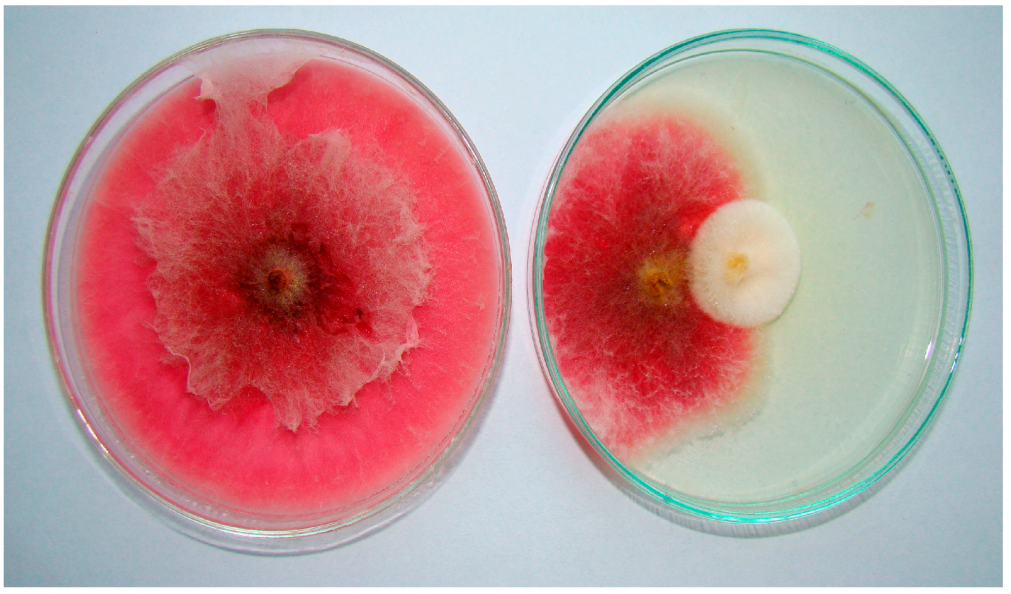

(a)

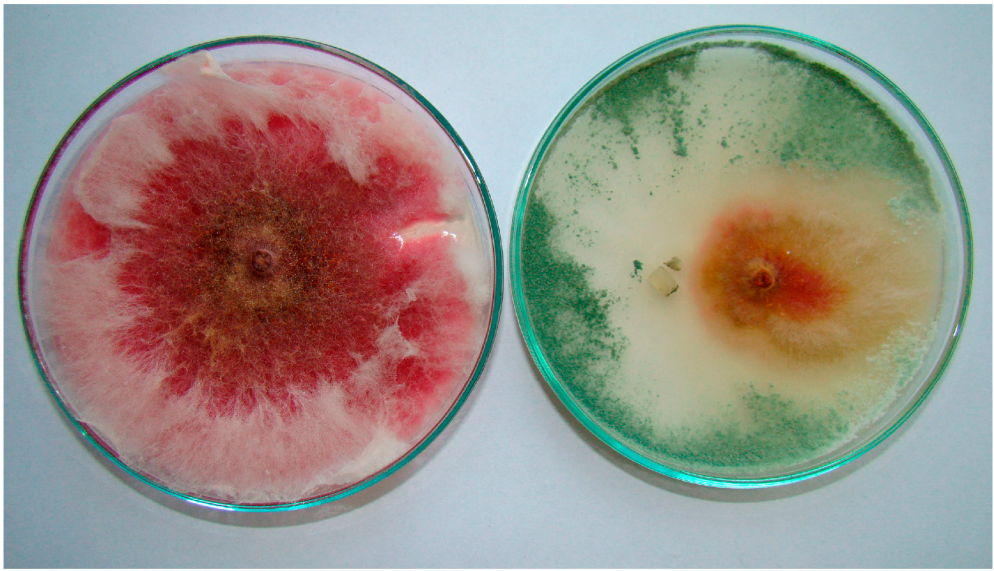

(b)

Figure 5. 10-day-old colonies of fungi on the potato dextrose agar (PDA) medium: (a) On the leftFusarium culmorum, on the right-Fusarium culmorum with Clonostachys rosea; (b) on the left-Fusarium culmorum, on the right-Fusarium culmorum with Trichoderma sp.; (photo by E. Patkowska).

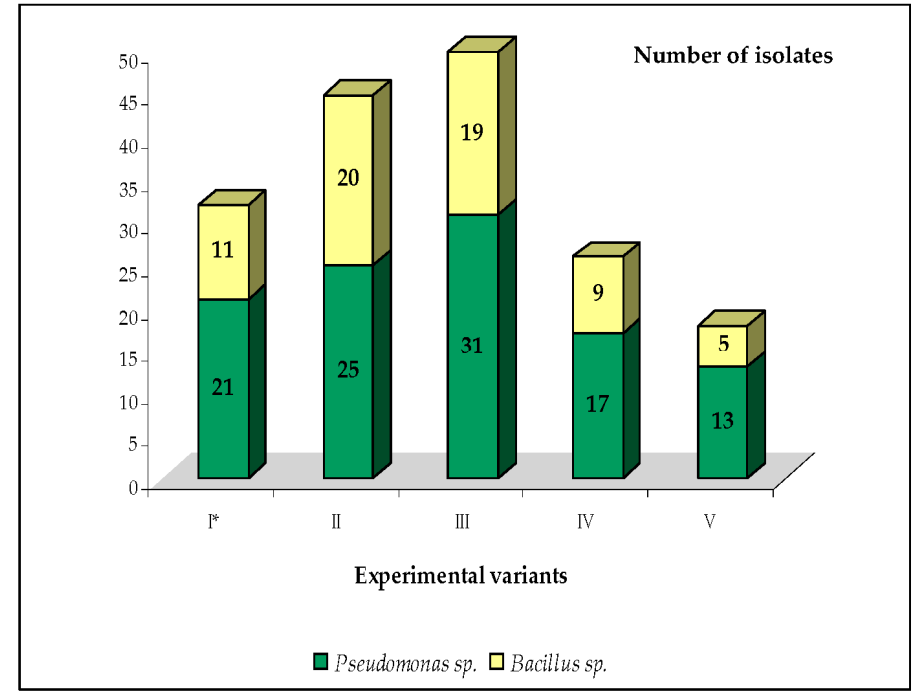

(a)

Figure 6. Cont. 


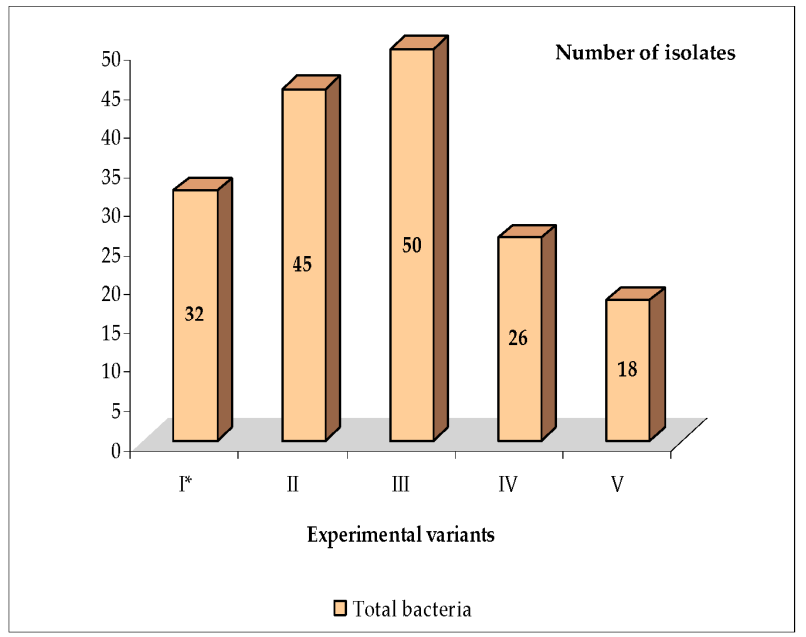

(b)

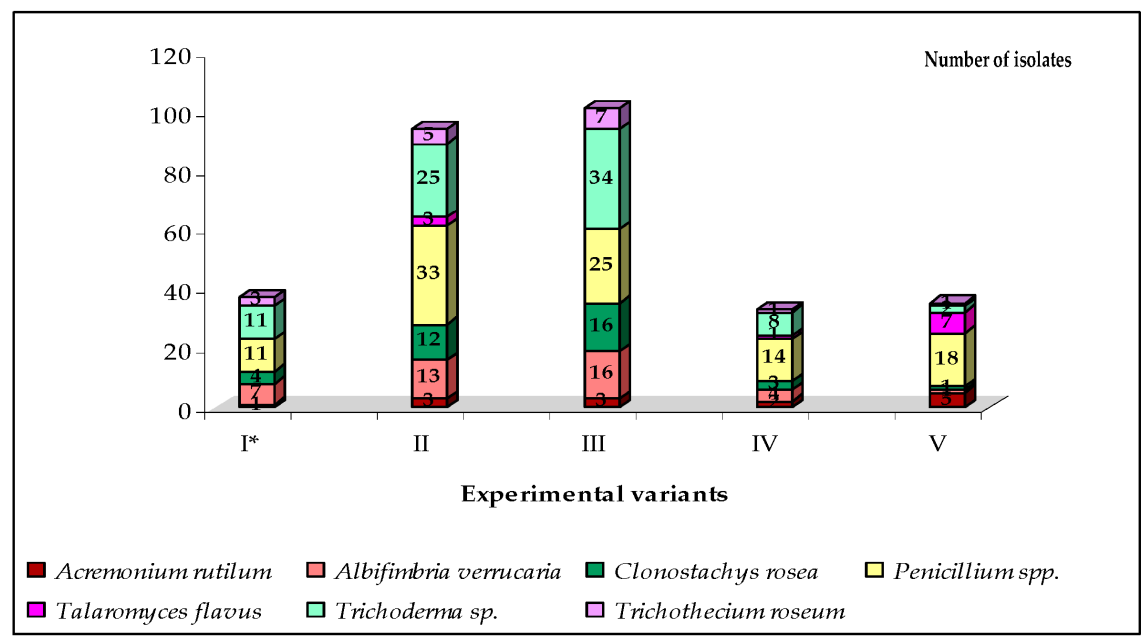

(c)

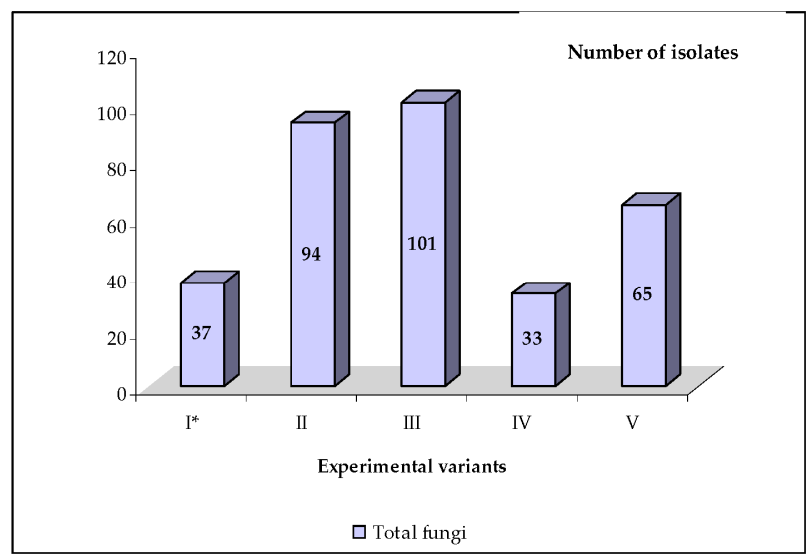

(d)

Figure 6. Antagonistic microorganisms in the rhizosphere of scorzonera: (a) Pseudomonas sp. and Bacillus sp.; (b) total bacteria; (c) antagonistic fungi; (d) total fungi. I*-Biosept Active, II-Timorex Gold 24 EC, III-Trianum P, IV—Zaprawa Nasienna T 75 DS/WS, V-control. 
Table 6. Antagonistic activity of selected fungi isolated from the scorzonera rhizosphere towards pathogenic fungi.

\begin{tabular}{|c|c|c|c|c|c|c|c|c|c|}
\hline \multirow{2}{*}{ Fungi } & \multirow{2}{*}{$\begin{array}{l}\text { Average Number of } \\
\text { Isolates (2014-2016) }\end{array}$} & \multicolumn{2}{|c|}{ Alternaria scorzonerae } & \multicolumn{2}{|c|}{ Fusarium culmorum } & \multicolumn{2}{|c|}{ Fusarium oxysporum } & \multicolumn{2}{|c|}{ Rhizoctonia solani } \\
\hline & & $\mathrm{IBE}^{*}$ & $\mathrm{GBE}^{* *}$ & $\mathrm{IBE}^{*}$ & $\mathrm{GBE}^{* *}$ & $\mathrm{IBE}^{*}$ & $\mathrm{GBE}^{* *}$ & $\mathrm{IBE}^{*}$ & $\mathrm{GBE}^{* *}$ \\
\hline \multicolumn{10}{|c|}{ Biosept Active } \\
\hline $\begin{array}{l}\text { Albifimbria verrucaria (Alb. and Schwein.) } \\
\text { L. Lombard and Crous }\end{array}$ & 7 & +6 & +42 & +4 & +28 & +3 & +21 & +4 & +28 \\
\hline $\begin{array}{c}\text { Clonostachys rosea (Link) Schroers, Samuels, } \\
\text { Seifert }\end{array}$ & 4 & +7 & +28 & +5 & +20 & +4 & +16 & +4 & +16 \\
\hline Penicillium decumbens Thom & 5 & +1 & +5 & +1 & +5 & +1 & +5 & +1 & +5 \\
\hline Trichoderma sp. & 11 & +8 & +88 & +8 & +88 & +8 & +88 & +8 & +88 \\
\hline Trichothecium roseum (Pers.) Link & 3 & +7 & +21 & +6 & +18 & +4 & +12 & +5 & +15 \\
\hline Number of isolates & 37 & & & & & & & & \\
\hline $\mathrm{SBE}^{* * *}$ & & & +200 & & +168 & & +150 & & +276 \\
\hline \multicolumn{10}{|c|}{ Timorex Gold 24 EC } \\
\hline Acremonium rutilum W. Gams & 3 & +4 & +12 & +3 & +12 & +2 & +6 & +2 & +6 \\
\hline $\begin{array}{c}\text { Albifimbria verrucaria (Alb. and Schwein.) } \\
\text { L. Lombard and Crous }\end{array}$ & 13 & +6 & +78 & +4 & +52 & +3 & +39 & +4 & +52 \\
\hline $\begin{array}{c}\text { Clonostachys rosea (Link) Schroers, Samuels, } \\
\text { Seifert }\end{array}$ & 12 & +7 & +84 & +5 & +60 & +4 & +48 & +4 & +48 \\
\hline Penicillium chermesinum Biourge & 14 & +2 & +28 & +1 & +14 & +1 & +14 & +2 & +28 \\
\hline Penicillium decumbens Thom & 15 & +1 & +15 & +1 & +15 & +1 & +15 & +1 & +15 \\
\hline Penicillium simplicissimum (Oudem.) Thom & 4 & +3 & +12 & +1 & +4 & +1 & +4 & +1 & +4 \\
\hline Talaromyces flavus (Klöcker) Stolk and Samson & 3 & +2 & +6 & +2 & +6 & +1 & +3 & +1 & +3 \\
\hline Trichoderma sp. & 25 & +8 & +200 & +8 & +200 & +8 & +200 & +8 & +200 \\
\hline Trichothecium roseum (Pers.) Link & 5 & +7 & +35 & +6 & +30 & +4 & +20 & +5 & +25 \\
\hline Number of isolates & 94 & & & & & & & & \\
\hline $\mathrm{SBE}^{* * *}$ & & & +470 & & +393 & & +349 & & +381 \\
\hline
\end{tabular}


Table 6. Cont.

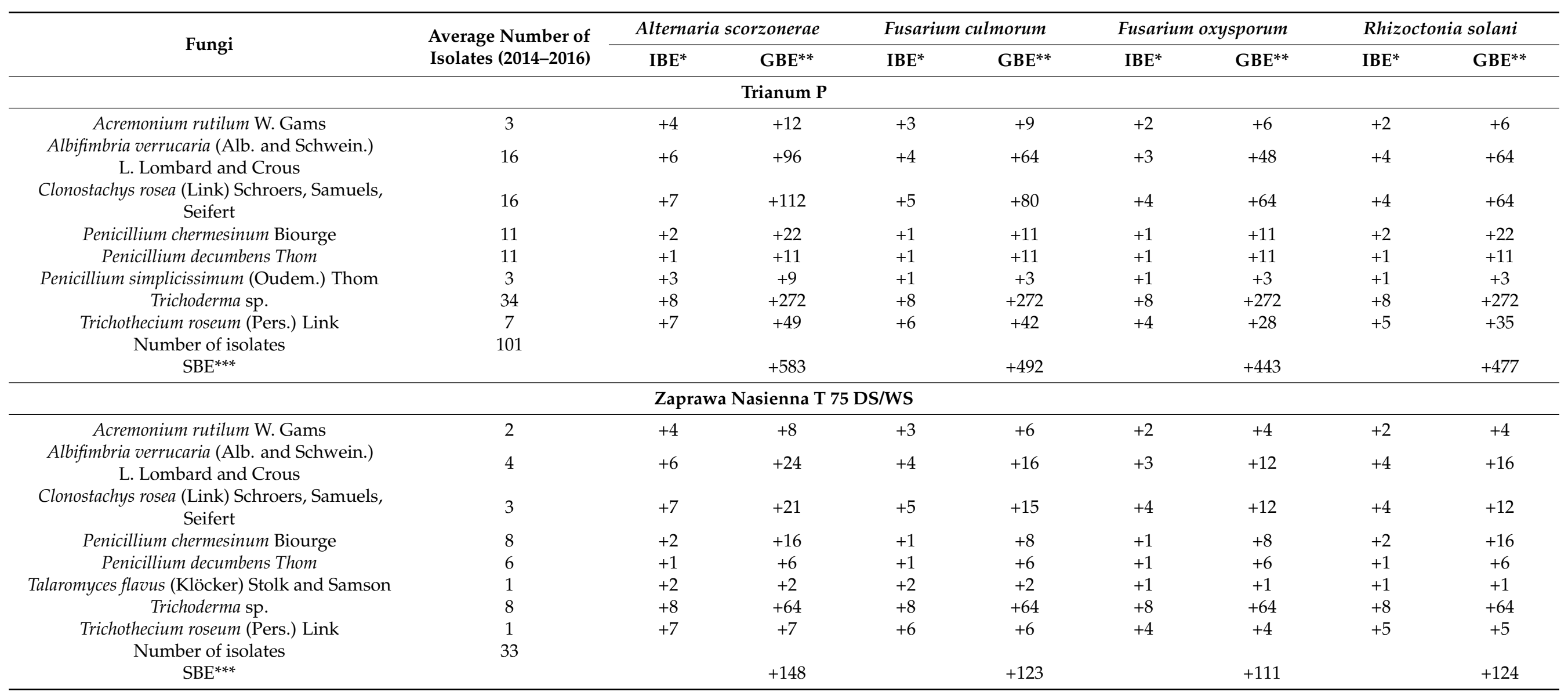


Table 6. Cont.

\begin{tabular}{|c|c|c|c|c|c|c|c|c|c|}
\hline \multirow{2}{*}{ Fungi } & \multirow{2}{*}{$\begin{array}{l}\text { Average Number of } \\
\text { Isolates (2014-2016) }\end{array}$} & \multicolumn{2}{|c|}{ Alternaria scorzonerae } & \multicolumn{2}{|c|}{ Fusarium culmorum } & \multicolumn{2}{|c|}{ Fusarium oxysporum } & \multicolumn{2}{|c|}{ Rhizoctonia solani } \\
\hline & & IBE* $^{*}$ & GBE** $^{* *}$ & IBE $^{*}$ & $\mathrm{GBE}^{* *}$ & IBE $^{*}$ & $\mathrm{GBE}^{* *}$ & IBE* $^{*}$ & GBE $^{* *}$ \\
\hline \multicolumn{10}{|c|}{ Control } \\
\hline Acremonium rutilum W. Gams & 5 & +4 & +20 & +3 & +15 & +2 & +10 & +2 & +10 \\
\hline $\begin{array}{l}\text { Albifimbria verrucaria (Alb. and Schwein.) } \\
\text { L. Lombard and Crous }\end{array}$ & 1 & +6 & +6 & +4 & +4 & +3 & +3 & +4 & +4 \\
\hline $\begin{array}{c}\text { Clonostachys rosea (Link) Schroers, Samuels, } \\
\text { Seifert }\end{array}$ & 1 & +7 & +7 & +5 & +5 & +4 & +4 & +4 & +4 \\
\hline Penicillium decumbens Thom & 3 & +1 & +3 & +1 & +3 & +1 & +3 & +1 & +3 \\
\hline Penicillium simplicissimum (Oudem.) Thom & 7 & +3 & +21 & +1 & +7 & +1 & +7 & +1 & +7 \\
\hline Talaromyces flavus (Klöcker) Stolk and Samson & 7 & +2 & +14 & +2 & +14 & +1 & +7 & +1 & +7 \\
\hline Trichoderma sp. & 2 & +8 & +16 & +8 & +16 & +8 & +16 & +8 & +16 \\
\hline Trichothecium roseum (Pers.) Link & 1 & +7 & +7 & +6 & +6 & +4 & +4 & +5 & +5 \\
\hline Number of isolates & 35 & & & & & & & & \\
\hline $\mathrm{SBE}^{* * *}$ & & & +110 & & +78 & & +62 & & +72 \\
\hline
\end{tabular}


Table 7. Antagonistic activity of bacteria isolated from the scorzonera rhizosphere towards pathogenic fungi.

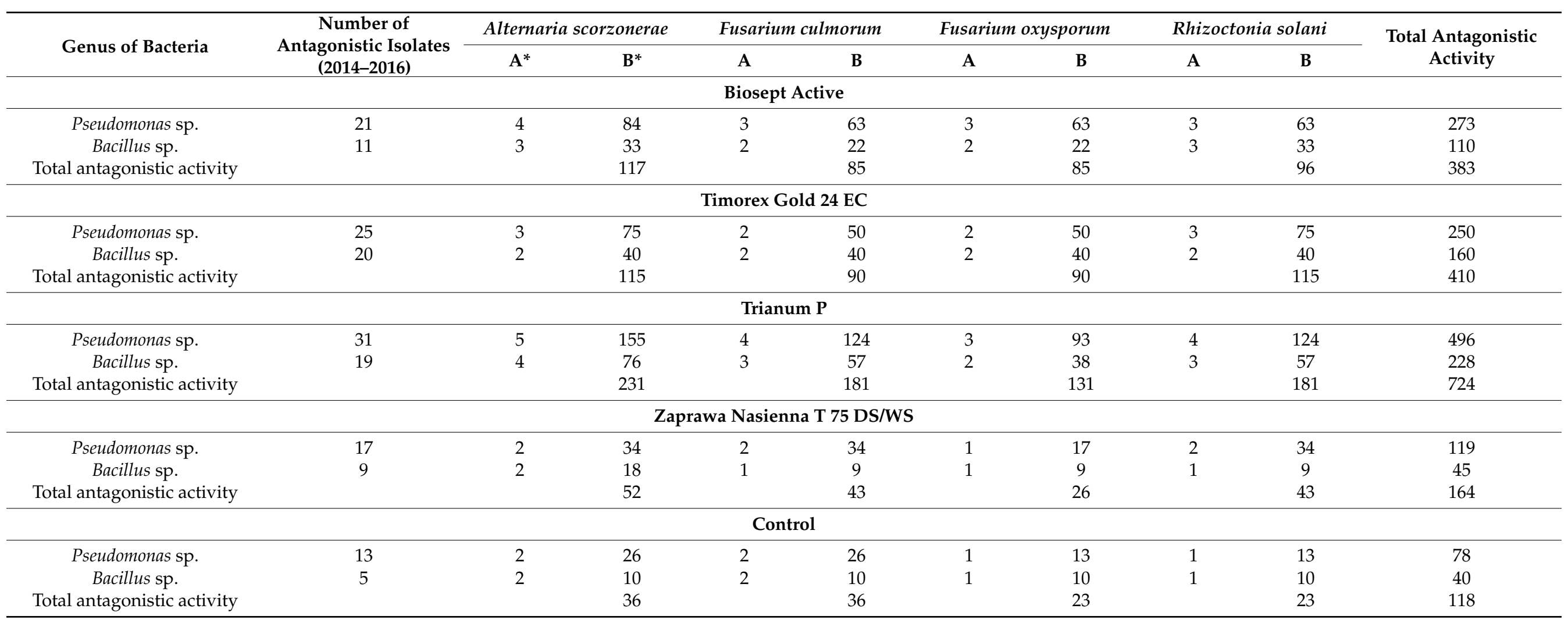

$\mathrm{A}^{*}$-individual antagonistic activity; $\mathrm{B}^{*}$ —general antagonistic activity; $\left(\mathrm{B}^{*}=\right.$ number of antagonistic isolates $\left.\times \mathrm{A}^{*}\right)$. 


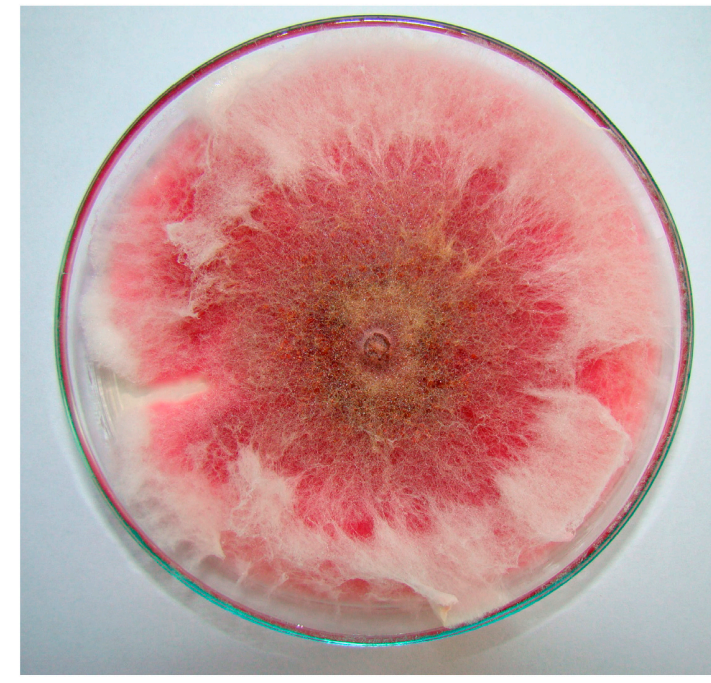

(a)

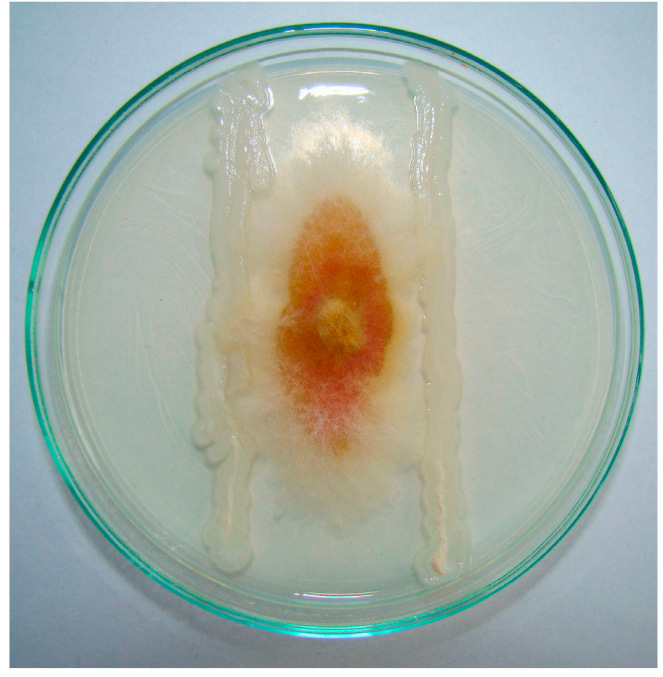

(b)

Figure 7. 10-day-old colonies of microorganisms on the potato dextrose agar (PDA) medium: (a) Fusarium culmorum; (b) Fusarium culmorum with Bacillus sp.; (photo by E. Patkowska).

\section{Discussion}

Biostimulants applied in scorzonera cultivation, namely Biosept Active (grapefruit extract), Timorex Gold 24 EC (tea tree oil) and Trianum P (spores of Trichoderma harzianum $\mathrm{T}-22) \mathrm{had}$ a positive effect on the health status of plants of the tested species. They effectively protected the roots of scorzonera against soil-borne pathogens. Tea tree oil and grapefruit extract turned out to be slightly less effective than Trichoderma harzianum T-22. Nevertheless, all the biostimulants used in the field experiment improved seed germination, emergence and root health of scorzonera in comparison with the control plants. Other studies confirmed the stimulating effect of pre-sowing seed treatment with grapefruit extract on the emergence, health status and yielding of plants from the family Fabaceae (such as pea, soybean, runner bean, and common bean) $[59,60,66,67]$. Tea tree oil stimulated seed germination and growth of carrot plants [6], while Trichoderma harzianum T-22 stimulated the germination and growth of maize and carrot plants $[6,68]$. Trichoderma harzianum T-22 spores are able to germinate and grow in various soils and different $\mathrm{pH}$ values (4-8.5) [69]. These spores, when present on the surface of seeds, can accelerate their germination and subsequently stimulate the growth of seedlings and older plants. Trichoderma harzianum $\mathrm{T}-22$ and grapefruit extract most effectively protected scorzonera roots against infection by soil-borne pathogens. Tea tree oil showed a slightly lower effectiveness. All biostimulants limited scorzonera root colonization by polyphages Alternaria alternata, Alternaria scorzonerae, Fusarium culmorum, Neocosmospora solani, Sclerotinia sclerotiorum, Fusarium oxysporum, and Rhizoctonia solani. On the other hand, they increased root colonization by beneficial saprotrophic fungi (Clonostachys rosea, Trichoderma sp., and Talaromyces flavus). Earlier studies demonstrated that Trichoderma harzianum T-22 and tea tree oil considerably improved the health status of carrot plants [6].

In the current study, the applied preparations modified fungal and bacterial communities in the scorzonera rhizosphere. Trichoderma harzianum T-22 and the fungicide significantly decreased the population of rhizospheric fungi. The efficiency of grapefruit extract and tea tree oil in limiting the development of rhizospheric fungi was slightly lower. Earlier studies also confirmed high effectiveness of Trichoderma harzianum T-22 and tea tree oil in limiting the population of soil-borne fungi in carrot cultivation [6]. Grapefruit extract and Trichoderma harzianum T-22 inhibited the development of pathogenic fungi of the genera Fusarium, Alternaria, Rhizoctonia, Sclerotinia, while they promoted the growth of antagonistic fungi of the genera Trichoderma, Trichothecium, Clonostachys, Albifimbria in 
the scorzonera rhizosphere. Many authors have reported the ability of various species of the genus Trichoderma, including Trichoderma harzianum T-22, to eliminate pathogenic fungi from the soil environment $[6,25,45-47,68]$. These fungi have the ability to grow rapidly, sporulate abundantly and survive in unfavorable conditions [70]. Trichoderma spp. colonize plant root surfaces similarly to mycorrhizal fungi [70]. Moreover, they are resistant to flavonoids, phytoalexins, phenols and terpenoids secreted by plants during infection [70]. They significantly modify the rhizosphere by affecting other soil microorganisms through competition, antibiotics and mycoparasitism [25,44-47]. They synthesize siderophores, lytic enzymes and secondary metabolites such as antibiotics $[44,45,47,71]$. They are able to lyse the cell walls, hyphae, and spores of harmful soil microorganisms [44,45]. Trichoderma spp. can produce volatile metabolites, including 6PAP (6-n-pentyl-6H-pyran-2-on, $6 \mathrm{PP})[35]$. This compound displays antifungal properties [72,73] and affects plant growth and leads to the development of systemic resistance [74,75]. According to Harel et al. [76], Trichoderma harzianum, when introduced to the soil, induced Fragaria ananassa resistance to powdery mildew caused by Podosphaera aphanis.

In the present study, Trichoderma harzianum T-22 and grapefruit extract more strongly stimulated the development of rhizobacteria populations, including antagonistic Pseudomonas sp. and Bacillus sp. than tea tree oil. The stimulating effect of grapefruit extract on the populations of these rhizobacteria was previously observed in common bean [63] and soybean cultivation [8]. Tea tree oil, chitosan, and Trichoderma harzianum T-22 increased the abundance of soil Pseudomonas sp. and Bacillus sp. in carrot cultivation [6]. These bacteria belong to the PGPR group and are also used as bacterial inoculants in organic farming $[77,78]$. These bacteria eliminate harmful microorganisms from the soil by producing substances toxic to pathogenic fungi (hydrolytic enzymes-chitinases, cellulases, proteases, various antibiotics and siderophores to competitively acquire ferric ion) $[39,40,43]$. A positive role of PGPR was observed in the cultivation of various horticultural plants $[33,35,78]$. Bacillus pumilus and Bacillus subtilis bacteria acted as biofertilizers in the cultivation of blackberry [35]. Pseudomonas fluorescens Pf5, introduced into the soil of highbush blueberry cultivation stimulated plant growth [79].

The biostimulants applied in scorzonera cultivation, especially Trichoderma harzianum $\mathrm{T}-22$, induced antagonistic activity of saprotrophic rhizosphere bacteria and fungi (Pseudomonas sp., Bacillus sp., Trichoderma sp., Clonostachys sp., Albifimbria verrucaria, and Trichothecium roseum) against the studied pathogenic fungi (Alternaria scorzonerae, Fusarium culmorum, Fusarium oxysporum, and Rhizoctonia solani). The antagonistic activity of various species of the genus Trichoderma against pathogenic microorgamisms has been described by many authors $[25,44,46,70]$. Trichoderma spp. (including T. harzianum T-22, T. longibrachiatum and T. atroviride) inhibited the growth and development of Alternaria alternata, Sclerotinia sclerotiorum, Fusarium spp., Rhizoctonia solani, Colletotrichum spp., and Diaporthe spp. $[6,48,80]$. Rhizospheric Trichoderma virens T2 and Trichoderma longibrachiatum T4 were antagonistic to Fusarium oxysporum f. sp. lycopersici and F. oxysporum f. sp. ciceris causing Fusarium wilt of tomato and chickpea [46]. Albifimbria verrucaria was effective as a biocontrol agent (BCA) against gray mold (Botrytis cinerea) [81]. Trichothecium roseum limited the development of Phakopsora pachyrhizi [82]. According to Hinarejos et al. [83], the rhizosphere may be a common selective source of Bacillus species that are useful in the biocontrol of phyllospheric and soil-borne pathogenic fungi. The effectiveness of rhizospheric Pseudomonas sp. in limiting the development of harmful soil microorganisms has been also confirmed by many authors $[6,84,85]$. The species Pseudomonas fluorescens, $P$. putida, P. cepacia, and P. chlororaphis showed high antagonistic activity against polyphagous fungi $[84,85]$. Pseudomonas fluorescens BRZ63 inhibited mycelium growth of Rhizoctonia solani, Colletotrichum dematium, Sclerotinia sclerotiorum, and Fusarium avenaceum [86].

The present study demonstrated the favorable effect of biostimulants on the antagonistic activity of beneficial microorganisms in the rhizosphere soil of scorzonera. Trichoderma harzianum T-22 and tea tree oil increased the population and activity of antagonists (Pseudomonas sp., Bacillus sp., Trichoderma sp., Clonostachys sp., Albifimbria verrucaria, and Tri- 
chothecium roseum) against phytopathogenic fungi to a greater extent than grapefruit extract. The fungicide Zaprawa Nasienna T 75 DS/WS was not conducive to the development of antagonistic bacteria and fungi. The effectiveness of tea tree oil and grapefruit extract could result from their antiseptic, bactericidal $[50,87]$ and fungicidal $[49,52-54,88]$ properties. Natural essential tea tree oil contains a maximum content $(15 \%)$ of 1,8 - cineole and a minimum content $(30 \%)$ of terpinen-4-ol, which is the main active constituent of the oil [49]. This biostimulant was effective in controlling plant-pathogenic fungi in numerous crops $[4,49,89]$. Tea tree oil showed high antagonistic activity against fungi such as Aspergillus fumigatus, Botrytis cinerea, Penicillium chrysogenum, Chaetomium globosum, Fusarium graminearum, F. oxysporum, F. culmorum, Ascochyta rabiei, Pyrenophora graminea, Colletotrichum lindemuthianum, Alternaria radicina, A. dauci, and Drechslera avenae $[49,52-54,88,89]$. The effectiveness of grapefruit extract in the elimination of harmful soil and phyllospheric microorganisms has been previously confirmed by many authors [7,56-60]. Its antiseptic properties result from the presence of biologically active compounds such as aliphatic aldehydes, monoterpenes and nutkaton [46]. According to Woedtke et al. [90], triclosan, 7-geranoxycoumarin, and benzetonine chloride present in grapefruit extract could inhibit the growth of bacteria and fungi. The positive influence of grapefruit extract on the composition of soil microorganisms was confirmed in the cultivation of plants from the family Fabaceae [59].

\section{Conclusions}

The current study showed the beneficial effect of biostimulants on the antagonistic activity of microorganisms in the rhizosphere soil of scorzonera, and thus on the health status of this plant in field cultivation. The biostimulants Biosept Active (grapefruit extract), Timorex Gold 24 EC (tea tree oil), and particularly Trianum P (Trichoderma harzianum Rifai $\mathrm{T}-22)$, exerted a positive influence on microbal communities in the rhizosphere. They reduced the population of pathogenic soil-borne fungi infecting scorzonera roots, while increasing the population of antagonistic bacteria and fungi, including Pseudomonas sp., Bacillus sp., Trichoderma sp., Clonostachys sp., Albifimbria verrucaria, and Trichothecium roseum. These microorganisms were characterized by high antagonistic activity towards the studied fungi pathogenic to scorzonera (Alternaria scorzonerae, Fusarium culmorum, Fusarium oxysporum, and Rhizoctonia solani). The biostimulants significantly improved the phytosanitary condition of the soil, and thus effectively protected the roots of scorzonera plants against infection by polyphagic soil-borne fungi. Therefore, they can be recommended in Scorzonera hispanica cultivation.

Author Contributions: Conceptualization, methodology, software, validation, formal analysis, investigation, data curation, writing — original draft preparation, writing — review and editing, visualization, E.P. All authors have read and agreed to the published version of the manuscript.

Funding: This research was funded the by the University of Life Sciences in Lublin, project OKF/DS/ 2/2014-2016.

Data Availability Statement: Data are contained within the article.

Acknowledgments: The author thanks reviewers for valuable comments that have enriched the content of the article.

Conflicts of Interest: The author declare no conflict of interest. The funders had no role in the design of the study; in the collection, analyses, or interpretation of data; in the writing of the manuscript, or in the decision to publish the results.

\section{References}

1. Mayer, Z.; Sasvári, Z.; Szentpéteri, V.; Rétháti, B.P.; Vajna, B.; Posta, K. Effect of Long-Term Cropping Systems on the Diversity of the Soil Bacterial Communities. Agronomy 2019, 9, 878. [CrossRef]

2. Lal, R. Restoring Soil Quality to Mitigate Soil Degradation. Sustainability 2015, 7, 5875-5895. [CrossRef]

3. Jangid, K.; Williams, M.A.; Franzluebbers, A.J.; Sanderlin, J.S.; Reeves, J.H.; Jenkins, M.B.; Endale, D.M.; Coleman, D.C.; Whitman, W.B. Relative impacts of land-use, management intensity and fertilization upon soil microbial community structure in agricultural systems. Soil Biol. Biochem. 2008, 40, 2843-2853. [CrossRef] 
4. Sommermann, L.; Geistlinger, J.; Wibberg, D.; Deubel, A.; Zwanzig, J.; Babin, D.; Schlüter, A.; Schellenberg, I. Fungal community profiles in agricultural soils of a long-term field trial under different tillage, fertilization and crop rotation conditions analyzed by high-throughput ITS-amplicon sequencing. PLOS ONE 2018, 13, e0195345. [CrossRef]

5. $\quad$ Meena, R.S.; Kumar, S.; Datta, R.; Lal, R.; Vijayakumar, V.; Brtnicky, M.; Sharma, M.P.; Yadav, G.S.; Jhariya, M.K.; Jangir, C.K.; et al. Impact of Agrochemicals on Soil Microbiota and Management: A Review. Land 2020, 9, 34. [CrossRef]

6. Patkowska, E.; Mielniczuk, E.; Jamiołkowska, A.; Skwaryło-Bednarz, B.; BłaŻewicz-Woźniak, M. The Influence of Trichoderma harzianum Rifai T-22 and Other Biostimulants on Rhizosphere Beneficial Microorganisms of Carrot. Agronomy 2020, $10,1637$. [CrossRef]

7. Jamiołkowska, A. Preparaty Biotechniczne i Biologiczne w Ochronie Papryki Słodkiej (Capsicum Annuum L.) Przed Grzybami Chorobotwórczymi i Indukowaniu Reakcji Obronnych Roślin, 1st ed.; Rozprawy Naukowe UP w Lublinie; University of Life Sciences in Lublin: Lublin, Poland, 2013; Volume 379, p. 117. Available online: https:/ / www.up.lublin.pl/5490/ (accessed on 20 February 2021).

8. Patkowska, E. The effect of biopreparations on the formation of rhizosphere microorganism populations of soybean (Glycine max (L.) Merrill). Acta Sci. Pol. Hortorum Cultus 2005, 4, 89-99.

9. Lupatini, M.; Korthals, G.W.; De Hollander, M.; Janssens, T.K.S.; Kuramae, E.E. Soil Microbiome Is More Heterogeneous in Organic Than in Conventional Farming System. Front. Microbiol. 2017, 7, 2064. [CrossRef]

10. Konopiński, M. Wpływ Zróżnicowanych Systemów Uprawy na Ksztattowanie Warunków Wzrostu, Plonowanie i Wartość Biologiczna Skorzonery (Scorzonera Hispanica L.), 1st ed.; Rozprawy Naukowe Akademii Rolniczej w Lublinie, University of Life Sciences in Lublin: Lublin, Poland, 2003; Volume 271, p. 93. Available online: https:/ / publikacje.up.lublin.pl (accessed on 20 February 2021).

11. Petkova, N. Characterization of Inulin from Black Salsify (Scorzonera Hispanica L.) for Food and Pharmaceutical Purposes. Asian J. Pharm. Clin. Res. 2018, 11, 221-225. [CrossRef]

12. Unal, O.; Göktürk, R.S. A new species of Scorzonera L. (Asteraceae) from south Anatolia, Turkey. Bot. J. Linn. Soc. 2003, 142, 465-468. [CrossRef]

13. Erden, Y.; Kırbağ, S.; Yılmaz, Ö. Phytochemical Composition and Antioxidant Activity of Some Scorzonera Species. Proc. Natl. Acad. Sci. India Sect. B Boil. Sci. 2012, 83, 271-276. [CrossRef]

14. Causey, J.L.; Feirtag, J.M.; Gallaher, D.D.; Tungland, B.C.; Slavin, J.L. Effects of dietary inulin on serum lipids, blood glucose and the gastrointestinal environment in hypercholesterolemic men. Nutr. Res. 2000, 20, 191-201. [CrossRef]

15. Konopiński, M. Influence of Intercrop Plants and Varied Tillage on Yields and Nutritional Value of Scorzonera (Scorzonera Hispanica L.) roots. Acta Sci. Pol. Hortorum Cultus 2011, 10, 49-59. Available online: http:/ /www.hortorumcultus.actapol.net/ volume10/issue1/10_1_49.pdf (accessed on 20 February 2021).

16. Grzyb, A.; Wolna-Maruwka, A.; Niewiadomska, A. Environmental Factors Affecting the Mineralization of Crop Residues. Agronomy 2020, 10, 1951. [CrossRef]

17. Patkowska, E.; Konopiński, M. Harmfulness of Soil-Borne Fungi towards Root Chicory (Cichorium intybus L. var. sativum Bisch.) Cultivated with the Use of Cover Crops. Acta Sci. Pol. Hortorum Cultus 2013, 12, 3-18. Available online: http: //www.hortorumcultus.actapol.net/volume12/issue4/12_4_3.pdf (accessed on 20 February 2021).

18. Patkowska, E.; Konopiński, M. Cover Crops and Soil-Borne Fungi Dangerous towards the Cultivation of Salsify (Tragopogon porrifolius var. sativus (Gaterau) Br.). Acta Sci. Pol. Hortorum Cultus 2011, 10, 167-181. Available online: http:/ / www.acta.media.pl (accessed on 20 February 2021).

19. Loerakker, W.M. A rare leaf spot disease of Scorzonera hispanica, caused by Alternaria scorzonerae (Aderhold) Comb. Nov. Eur. J. Plant Pathol. 1984, 90, 35-39. [CrossRef]

20. Choi, Y.-J.; Thines, M. Host Jumps and Radiation, Not Co-Divergence Drives Diversification of Obligate Pathogens. A Case Study in Downy Mildews and Asteraceae. PLoS ONE 2015, 10, e0133655. [CrossRef] [PubMed]

21. Patkowska, E.; Konopiński, M. Pathogenicity of selected soil-borne microorganisms for scorzonera seedlings (Scorzonera hispanica L.). Folia Hortic. 2008, 20, 31-42. [CrossRef]

22. Patkowska, E.; Konopiński, M. Fungi threatening scorzonera (Scorzonera hispanica L.) cultivation using plant mulches. Acta Sci. Pol. Hortorum Cultus 2013, 12, 215-225.

23. Vejan, P.; Abdullah, R.; Khadiran, T.; Ismail, S.; Boyce, A.N. Role of Plant Growth Promoting Rhizobacteria in Agricultural Sustainability-A Review. Molecules 2016, 21, 573. [CrossRef]

24. Khan, N.; Bano, A.M.D.; Babar, M.D.A. Impacts of plant growth promoters and plant growth regulators on rainfed agriculture. PLoS ONE 2020, 15, e0231426. [CrossRef]

25. Woo, S.L.; Ruocco, M.; Vinale, F.; Nigro, M.; Marra, R.; Lombardi, N.; Pascale, A.; Lanzuise, S.; Manganiello, G.; Lorito, M. Trichoderma-based Products and their Widespread Use in Agriculture. Open Mycol. J. 2014, 8, 71-126. [CrossRef]

26. Ricci, M.; Tilbury, L.; Daridon, B.; Sukalac, K. General Principles to Justify Plant Biostimulant Claims. Front. Plant Sci. 2019, 10, 494. [CrossRef]

27. Du Jardin, P. Plant biostimulants: Definition, concept, main categories and regulation. Sci. Hortic. 2015, 196, 3-14. [CrossRef]

28. Malik, A.; Mor, V.S.; Tokas, J.; Punia, H.; Malik, S.; Malik, K.; Sangwan, S.; Tomar, S.; Singh, P.; Singh, N.; et al. Biostimulant-Treated Seedlings under Sustainable Agriculture: A Global Perspective Facing Climate Change. Agronomy 2020, 11, 14. [CrossRef]

29. Yakhin, O.I.; Lubyanov, A.A.; Yakhin, I.A.; Brown, P.H. Biostimulants in Plant Science: A Global Perspective. Front. Plant Sci. 2017, 7, 2049. [CrossRef] [PubMed] 
30. Drobek, M.; Frąc, M.; Cybulska, J. Plant Biostimulants: Importance of the Quality and Yield of Horticultural Crops and the Improvement of Plant Tolerance to Abiotic Stress-A Review. Agronomy 2019, 9, 335. [CrossRef]

31. Le Mire, G.; Nguyen, M.L.; Fassotte, B.; du Jardin, P.; Verheggen, F.; Delaplace, P.; Jijakli, M.H. Implementing plant biostimulants and biocontrol strategies in the agroecological management of cultivated ecosystems. A review. Biotechnol. Agron. Soc. Environ. 2016, 20, 299-313. [CrossRef]

32. Calvo, P.; Nelson, L.; Kloepper, J.W. Agricultural uses of plant biostimulants. Plant Soil 2014, 383, 3-41. [CrossRef]

33. Seema, K.; Mehta, K.; Singh, N. Studies on the Effect of Plant Growth Promoting Rhizobacteria (PGPR) on Growth, Physiological Parameters, Yield and Fruit Quality of Strawberry cv. Chandler. J. Pharmacog. Phytochem. 2018, 7, 383-387. Available online: https:// www.phytojournal.com (accessed on 20 February 2021).

34. Gaiero, J.R.; McCall, C.A.; Thompson, K.A.; Day, N.J.; Best, A.S.; Dunfield, K.E. Inside the root microbiome: Bacterial root endophytes and plant growth promotion. Am. J. Bot. 2013, 100, 1738-1750. [CrossRef] [PubMed]

35. Robledo-Buriticá, J.; Aristizábal-Loaiza, J.C.; Ceballos-Aguirre, N.; Cabra-Cendales, T. Influence of plant growth-promoting rhizobacteria (PGPR) on blackberry (Rubus glaucus Benth. cv. Thornless) growth under semi-cover and field conditions. Acta Agron. 2018, 67, 258-263. [CrossRef]

36. Colla, G.; Rouphael, Y.; Di Mattia, E.; El-Nakhel, C.; Cardarelli, M. Co-inoculation of Glomus intraradices and Trichoderma atroviride acts as a biostimulant to promote growth, yield and nutrient uptake of vegetable crops. J. Sci. Food Agric. 2015, 95, 1706-1715. [CrossRef] [PubMed]

37. Usuki, F.; Narisawa, K. A mutualistic symbiosis between a dark septate endophytic fungus, Heteroconium chaetospira, and a nonmycorrhizal plant, Chinese cabbage. Mycologia 2007, 99, 175-184. [CrossRef] [PubMed]

38. Jamiołkowska, A.; Skwaryło-Bednarz, B.; Patkowska, E.; Buczkowska, H.; Gałązka, A.; Grządziel, J.; Kopacki, M. Effect of Mycorrhizal Inoculation and Irrigation on Biological Properties of Sweet Pepper Rhizosphere in Organic Field Cultivation. Agronomy 2020, 10, 1693. [CrossRef]

39. Chandrasekaran, M.; Belachew, S.T.; Yoon, E.; Chun, S.C. Expression of $\beta$-1,3-glucanase (GLU) and phenylalanine ammonia-lyase (PAL) genes and their enzymes in tomato plants induced after treatment with Bacillus subtilis CBR05 against Xanthomonas campestris pv. vesicatoria. J. Gen. Plant Pathol. 2016, 83, 7-13. [CrossRef]

40. Gouda, S.; Kerry, R.G.; Das, G.; Paramithiotis, S.; Shin, H.-S.; Patra, J.K. Revitalization of plant growth promoting rhizobacteria for sustainable development in agriculture. Microbiol. Res. 2018, 206, 131-140. [CrossRef] [PubMed]

41. Abbo, A.Z.; Idris, M.O.; Hammad, A.M. The Antifungal Effects of Four Tomato Rhizosphere Bacillus spp. against Alternaria alternata. Inter. J. Sci. Res. 2014, 3, 1324-1328.

42. Ma, G.-Z. Purification and characterization of chitinase from Gliocladium catenulatum strain HL-1-1. Afr. J. Microbiol. Res. 2012, 6, 4377-4383. [CrossRef]

43. Ahmed, E.; Holmström, S.J.M. Siderophores in environmental research: Roles and applications. Microb. Biotechnol. 2014, 7, 196-208. [CrossRef]

44. Chet, I.; Harman, G.E.; Baker, R. Trichoderma hamatum: Its hyphal interactions with Rhizoctonia solani and Pythium spp. Microb. Ecol. 1981, 7, 29-38. [CrossRef]

45. Sivan, A.; Chet, I. Degradation of Fungal Cell Walls by Lytic Enzymes of Trichoderma harzianum. Microbiology 1989, 135, 675-682. [CrossRef]

46. Sonkar, P.; Pritam, M. Dynamics of Trichoderma spp. against Fusarium wilt based on in vitro and in silico. J. Biopest. 2020, 13, 97-102.

47. Contreras-Cornejo, H.A.; Macías-Rodríguez, L.; Del-Val, E.; Larsen, J. Ecological functions of Trichoderma spp. and their secondary metabolites in the rhizosphere: Interactions with plants. FEMS Microbiol. Ecol. 2016, 92, fiw036. [CrossRef]

48. Jamiołkowska, A.; Hetman, B. Mechanizm działania preparatów biologicznych stosowanych w ochronie roślin przed patogenami. Ann. UMCS Sectio E Agric. 2016, 71, 13-29.

49. Reuveni, M.; Sanches, E.; Barbier, M. Curative and Suppressive Activities of Essential Tea Tree Oil against Fungal Plant Pathogens. Agronomy 2020, 10, 609. [CrossRef]

50. Carson, C.F.; Hammer, K.A.; Riley, T.V. Melaleuca alternifolia (Tea Tree) Oil: A Review of Antimicrobial and Other Medicinal Properties. Clin. Microbiol. Rev. 2006, 19, 50-62. [CrossRef]

51. Rudbäck, J.; Bergström, M.A.; Börje, A.; Nilsson, U.; Karlberg, A.-T. $\alpha$-Terpinene, an Antioxidant in Tea Tree Oil, Autoxidizes Rapidly to Skin Allergens on Air Exposure. Chem. Res. Toxicol. 2012, 25, 713-721. [CrossRef]

52. Terzi, V.; Morcia, C.; Faccioli, P.; Valè, G.; Tacconi, G.; Malnati, M. In vitro antifungal activity of the tea tree (Melaleuca alternifolia) essential oil and its major components against plant pathogens. Lett. Appl. Microbiol. 2007, 44, 613-618. [CrossRef]

53. KhangLE, T.; HuongNguyen, T.; TienLE, T. Antifungal Activity of Tea Tree Essential Oils (Melaleuca Alternifolia) Against Phytopathogenic Fungi. Int. J. Adv. Res. 2019, 7, 1239-1248. [CrossRef]

54. Yu, D.; Wang, J.; Shao, X.; Xu, F.; Wang, H. Antifungal modes of action of tea tree oil and its two characteristic components against Botrytis cinerea. J. Appl. Microbiol. 2015, 119, 1253-1262. [CrossRef] [PubMed]

55. Céliz, G.; Daz, M.; Audisio, M. Antibacterial activity of naringin derivatives against pathogenic strains. J. Appl. Microbiol. 2011, 111, 731-738. [CrossRef]

56. Pięta, D.; Patkowska, E.; Pastucha, A. Oddziaływanie biopreparatów na wzrost i rozwój niektórych grzybów chorobotwórczych dla roślin motylkowatych. Acta Sci. Pol. Hortorum Cultus 2004, 3, 117-177. 
57. Kurzawińska, H.; Mazur, S. The application of some biotechnical preparations in potato protection against Phytophthora infestans. Phytopathology 2012, 63, 31-37.

58. Orlikowski, L.B.; Skrzypczak, C. Biocides in the control of soil-borne and leaf pathogens. Hortic. Veget. Grow. 2003, $22,426-433$.

59. Patkowska, E. Effect of Miedzian $50 \mathrm{WP}$ and grapefruit extract on the healthiness and communities of soil microorganisms of pea (Pisum sativum L.). Acta Sci. Pol. Hortorum Cultus 2014, 13, 23-33.

60. Patkowska, E. Effectiveness of grapefruit extract and Pythium oligandrum in the control of bean and peas pathogens. J. Plant Protect. Res. 2006, 46, 15-28.

61. Patkowska, E.; Krawiec, M. Yielding and healthiness of pea cv. 'Sześciotygodniowy TOR' after applying biotechnical preparations. Acta Sci. Pol. Hortorum Cultus 2016, 15, 143-156.

62. Czaban, J.; Gajda, A.; Wróblewska, B. The mobility of bacteria from rhizosphere and different zones of winter wheat roots. Pol. J. Environ. Stud. 2007, 16, 301-308.

63. Patkowska, E. Effect of bio-products on bean yield and bacterial and fungal communities in the rhizosphere and non-rhizosphere. Pol. J. Environ. Stud. 2009, 18, 255-263.

64. Jamiołkowska, A.; Skwaryło-Bednarz, B.; Patkowska, E. Morphological Identity and Population Structure of Hemibiotrophic Fungus Colletotrichum Coccodes Colonizing Pepper Plants. Acta Sci. Pol. Hortorum Cultus 2018, 17, 181-192. [CrossRef]

65. Patkowska, E.; Błażewicz-Woźniak, M. The microorganisms communities in the soil under the cultivation of carrot (Daucus carota L.). Acta Sci. Pol. Hortorum Cultus 2014, 13, 103-115.

66. Patkowska, E. The Effect of Biopreparations on the Healthiness of Soybean Cultivated in a Growth Chamber Experiment. Electr. J. Pol. Agric. Univer. Hortic. 2005, 8, 8. Available online: http://www.ejpau.media.pl/volume8/issue4/art.-08.html (accessed on 20 February 2021).

67. Pięta, D.; Patkowska, E.; Pastucha, A. The protective effect of biopreparations applied as the dressing for common bean (Phaseolus vulgaris L.) and pea (Pisum sativum L.). Acta Sci. Pol. Hortorum Cultus 2005, 4, 59-67.

68. Ferrigo, D.; Raiola, A.; Picollo, E.; Scopel, C.; Causin, R. Trichoderma harzianum T22 induces in maize systemic resistance against Fusarium verticillioides. J. Plant. Pathol. 2014, 96, 133-142. [CrossRef]

69. Pylak, M.; Oszust, K.; Frąc, M. Review report on the role of bioproducts, biopreparations, biostimulants and microbial inoculants in organic production of fruit. Rev. Environ. Sci. Bio/Technol. 2019, 18, 597-616. [CrossRef]

70. Wojtkowiak-Gębarowska, E. Mechanizmy zwalczania fitopatogenów glebowych przez grzyby z rodzaju Trichoderma. Post. Mikrobiol. 2006, 45, 261-273.

71. Strakowska, J.; Błaszczyk, L.; Chełkowski, J. The significance of cellulolytic enzymes produced by Trichoderma in opportunistic lifestyle of this fungus. J. Basic Microbiol. 2014, 54, S2-S13. [CrossRef]

72. Poole, P.R.; Ward, B.G.; Whitaker, G. The effects of topical treatments with 6-pentyl-2-pyrone and structural analogues on stem end postharvest rots in kiwifruit due to Botrytis cinerea. J. Sci. Food Agric. 1998, 77, 81-86. [CrossRef]

73. Tarus, P.; Lang'At-Thoruwa, C.; Wanyonyi, A.; Chhabra, S. Bioactive metabolites from Trichoderma harzianum and Trichoderma longibrachiatum. Bull. Chem. Soc. Ethiop. 2004, 17, 185-190. [CrossRef]

74. El-Hasan, A.; Buchenauer, H. Actions of 6-Pentyl-alpha-pyrone in Controlling Seedling Blight Incited by Fusarium moniliforme and Inducing Defence Responses in Maize. J. Phytopathol. 2009, 157, 697-707. [CrossRef]

75. Vinale, F.; Sivasithamparam, K.; Ghisalberti, E.; Marra, R.; Barbetti, M.; Li, H.; Woo, S.; Lorito, M. A novel role for Trichoderma secondary metabolites in the interactions with plants. Physiol. Mol. Plant Pathol. 2008, 72, 80-86. [CrossRef]

76. Harel, Y.M.; Kolton, M.; Elad, Y.; Rav-david, D.; Cytryn, E.; Borenstein, M.; Shulchani, R.; Graber, E.R. Induced systemic resistance in strawberry (Fragaria ananassa) to powdery mildew using various control agents. IOBC/Wprs. Bull. 2011, 71, 47-51.

77. Sas-Paszt, L.; Sumorok, B.; Derkowska, E.; Trzciński, P.; Lisek, A.; Grzyb, Z.S.; Sitarek, M.; Przybył, M.; Frąc, M. Effect of microbiologically enriched fertilizers on the vegetative growth of strawberry plants under field conditions in the first year of plantation. J. Res. Appl. Agric. Engin. 2019, 64, 29-37.

78. Esitken, A.; Yildiz, H.E.; Ercisli, S.; Donmez, M.F.; Turan, M.; Gunes, A. Effects of plant growth promoting bacteria (PGPB) on yield, growth and nutrient contents of organically grown strawberry. Sci. Hortic. 2010, 124, 62-66. [CrossRef]

79. De Silva, A.; Patterson, K.; Rothrock, C.; Moore, J. Growth Promotion of Highbush Blueberry by Fungal and Bacterial Inoculants. HortScience 2000, 35, 1228-1230. [CrossRef]

80. Smolińska, U.; Kowalska, B. Biological control of the soil-borne fungal pathogen Sclerotinia sclerotiorum-A review. J. Plant Pathol. 2018, 100, 1-12. [CrossRef]

81. Li, Z.; Chang, M.P.P.; Gao, M.L.L.; Wang, X. The Endophytic Fungus Albifimbria verrucaria from Wild Grape as an Antagonist of Botrytis cinerea and Other Grape Pathogens. Phytopathology 2020, 110, 843-850. [CrossRef] [PubMed]

82. Kumar, S.; Jha, D.K. Trichothecium roseum: A potential agent for the biological control of soybean rust. Ind. Phytopathol. 2002, 55, 232-234.

83. Hinarejos, E.; Castellano, M.; Rodrigo, I.; Bellés, J.M.; Conejero, V.; López-Gresa, M.P.; Lisón, P. Bacillus subtilis IAB /BS03 as a potential biological control agent. Eur. J. Plant Pathol. 2016, 146, 597-608. [CrossRef]

84. Goel, A.; Sindhu, S.; Dadarwal, K. Pigment Diverse Mutants of Pseudomonas sp.: Inhibition of Fungal Growth and Stimulation of Growth of Cicer arietinum. Biol. Plant. 2000, 43, 563-569. [CrossRef]

85. Srivastava, R.; Shalini, R. Antifungal activity of Pseudomonas fluorescens against different plant pathogenic fungi. Int. J. Microbiol. 2008, 7, 2789-2796. 
86. Chlebek, D.; Pinski, A.; Żur, J.; Michalska, J.; Hupert-Kocurek, K. Genome Mining and Evaluation of the Biocontrol Potential of Pseudomonas fluorescens BRZ63, a New Endophyte of Oilseed Rape (Brassica napus L.) against Fungal Pathogens. Int. J. Mol. Sci. 2020, 21, 8740. [CrossRef]

87. Cox, S.D.; Mann, C.M.; Markham, J.L.; Gustafson, J.E.; Warmington, J.R.; Wyllie, S.G. Determining the Antimicrobial Actions of Tea Tree Oil. Molecules 2001, 6, 87-91. [CrossRef]

88. Shao, X.; Cheng, S.; Wang, H.; Yu, D.; Mungai, C. The possible mechanism of antifungal action of tea tree oil on Botrytis cinerea. J. Appl. Microbiol. 2013, 114, 1642-1649. [CrossRef] [PubMed]

89. Reuveni, M.; Neifeld, D.; Dayan, D.; Kotzer, Y. BM-608-A Novel Organic Product Based on Essential Tea Tree Oil for the Control of Fungal Diseases in Tomato. Acta Hortic. 2009, 808, 129-132. [CrossRef]

90. Woedtke, T.; Schluter, B.; Pflegel, P.; Lindequist, U.; Julich, W.D. Aspects of the antimicrobial efficacy of grapefruit seed extract and its selection to preservative substances contained. Pharmazie 1999, 54, 452-456. [PubMed] 